\author{
Marcin Lugawiak \\ Uniwersytet Ekonomiczny we Wrocławiu \\ e-mail: marcin.lugawiak@gmail.com \\ ORCID: 0000-0002-8405-107X
}

\title{
STRATEGIE GMIN W POLSCE W LATACH 2011-2018. PERSPEKTYWA PODEJŚĆ DO STRATEGII
}

DOI: $10.15611 / \mathrm{pn} .2021 .1 .06$

JEL Classification: H700

\section{(C) 2021 Marcin Ługawiak}

Praca opublikowana na licencji Creative Commons Uznanie autorstwa-Na tych samych warunkach 4.0 Międzynarodowe (CC BY-SA 4.0). Skrócona treść licencji na https://creativecommons.org/licenses/by-sa/4.0/deed.pl

Cytuj jako: Ługawiak, M. (2021). Strategie gmin w Polsce w latach 2011-2018. Perspektywa podejść do strategii. Prace Naukowe Uniwersytetu Ekonomicznego we Wrocławiu, 65(1).

Streszczenie: Celem przeprowadzonych badań było określenie preferencji dotyczących podejścia do strategii w gminach polskich. Wyniki badań dały podstawę, aby uznać, że w gminach polskich dominuje planistyczne podejście do strategii, którego przejawem jest koncentracja na zasobach materialnych, czynnikach wewnętrznych, i w mniejszym stopniu podejście zasobowe, skoncentrowane na zasobach niematerialnych i, podobnie jak podejście planistyczne, na czynnikach wewnętrznych. Podejście pozycyjne zorientowane na zasoby odróżniające i postulaty dotyczące zwiększenia udziału w rynku, podejście innowacyjne, w którym gminy koncentrują się na wykreowaniu innowacji i podejście sieciowe zorientowane na zasoby relacyjne i wykorzystanie sieci w rozwoju, choć mają uzasadnienie z perspektywy działalności i rozwoju samorządu gminnego, są w małym zakresie praktykowane przez gminy.

Słowa kluczowe: zarządzanie strategiczne, strategie gminne, teoria strategii.

\section{Wstęp}

Problematyka podejścia do strategii jest przedmiotem wielu prac teoretycznych i badań empirycznych, jednak uwaga badaczy zogniskowana jest na przedsiębiorstwie i ewolucji zachodzącej w podejściu do strategii w sektorze przedsiębiorstw. Jednostki samorządu terytorialnego od wielu lat stosują planowanie strategiczne i zarządzają rozwojem według zasad zaczerpniętych z metod stosowanych przez przedsiębiorstwa, rozwijając jednocześnie te metody. Nie ulega więc wątpliwości, że planowanie i zarządzanie strategiczne w samorządzie terytorialnym jest obecnie odrębnym zagadnieniem w nauce i praktyce. Gmina jest jednostką samorządu tery- 
torialnego i w ujęciu prawnym (Ustawa z dnia 8 marca 1990 r.) należy ją rozumieć jako wspólnotę samorządową oraz odpowiednie terytorium. Zgodnie z ustawą o samorządzie gminnym gmina wykonuje zadania publiczne. Do kompetencji rady gminy będącej jej organem należy m.in. uchwalanie programów gospodarczych. Zgodnie z przyjętą praktyką legislacyjną przez pojęcie programu gospodarczego rozumie się m.in. strategię rozwoju.

Obserwując działalność gmin w Polsce, można dojść do wniosku, że pod wieloma względami zachowują się jak organizacje o celach i formie zarządzania bliskich naturze przedsiębiorstw (Markowski, 1999, s. 16). Zdecydowana większość gmin ma sformalizowane strategie rozwoju i określa cele działalności, których podstawą jest zdobycie przewagi konkurencyjnej i pozyskanie zasobów, na których im zależy. Zysk, który stał się powszechnie synonimem celu funkcjonowania firm, jest zupełnie nieistotny dla gmin. Jego miejsce w przypadku jednostki samorządu terytorialnego zastępuje korzyść społeczna rozumiana czynnościowo jako zaspokojenie potrzeb mieszkańców, przedsiębiorstw i innych podmiotów zlokalizowanych na terytorium gminy, materialnie zaś - jako zasób oddany do korzystania, czy pozamaterialnie - jako przekazane wiedza i umiejętności. Pomnażanie korzyści społecznych może się natomiast odbywać w sposób $\mathrm{w}$ wielu aspektach zbieżny z pomnażaniem zysku.

Celem przeprowadzonych badań, których wyniki zamieszczono w artykule, jest dokonanie analizy wykorzystania przez gminy w Polsce teoretycznych założeń wybranych podejść do strategii.

Główna hipoteza badawcza została określona w następujący sposób: w gminach polskich dominuje planistyczne podejście do strategii, którego przejawem jest koncentracja na zasobach materialnych i wewnętrznych czynnikach rozwojowych, a w mniejszym stopniu podejście zasobowe, którego podstawą jest koncentracja na zasobach niematerialnych oraz, podobnie jak w przypadku podejścia planistycznego, na potencjale i czynnikach wewnętrznych. Podejścia pozycyjne, innowacyjne i sieciowe, choć mają uzasadnienie z perspektywy działalności i rozwoju samorządu gminnego, są w małym zakresie praktykowane przez gminy. Główna hipoteza została ustalona na podstawie wiedzy eksperckiej autora wywodzącej się również z przeprowadzonych wielu działań związanych z opracowaniem strategii gminy, z których wynika, że gminy ograniczone działalnością do stosunkowo niewielkiego terytorium i podejmujące się zarządzania majątkiem publicznym pomijają szanse rozwojowe wynikające $\mathrm{z}$ renty pozycyjnej, sieciowej i innowacyjnej ${ }^{1}$.

Dodatkowe hipotezy badawcze wynikają z założenia, że gminy będą się różnić podejściem do strategii ze względu na to, jakiego typu z funkcjonalnego punktu widzenia są jednostkami:

${ }^{1}$ Hipotezy badawcze zostały przedyskutowane z J. Niemczykiem - autorem monografii poświęconej podejściu do strategii (Niemczyk, 2013). 
- duże miasta - stolice regionów w większym stopniu przejawiają w planowaniu strategicznym cechy podejścia innowacyjnego, mając na uwadze kapitał naukowy i cechy podejścia sieciowego ze względu na rozwój funkcji aglomeracyjnych,

- gminy aglomeracyjne w większym stopniu przejawiają w planowaniu strategicznym cechy podejścia sieciowego ze względu na silne powiązania z innymi gminami wewnątrz aglomeracji.

Metoda badań dokumentów w toku analizy celów badania i jego ograniczeń została uznana za najlepszą do zastosowania. Niemal wszystkie jednostki samorządu terytorialnego posiadają spisaną i przyjętą formalnie przez organy uchwałodawcze strategię. Jest to zatem doskonały materiał do badan i porównań, który reprezentuje całą objętą badaniem populację. Metoda badań dokumentów polega głównie na selekcji, opisie i interpretacji faktów zawartych w tych dokumentach. Analizie zostały poddane części postulatywne wszystkich strategii. W tym wypadku nie było istotne to, jakie konkretnie cele i zadania zostały przez gminy zaplanowane, ale jakiego rodzaju są to cele i zadania, z jaką sferą rozwoju powiązane.

\section{Zalożenia poznawcze podejść do strategii}

Pojęciami pokrewnymi dla kategorii podejście do strategii mogą być: koncepcja strategii, szkoła strategii, logika strategii czy bardziej potocznie - myślenie o strategii. O ile strategia i jej istota stały się przedmiotem nauk o zarządzaniu w latach pięćdziesiątych XX wieku, o tyle pierwsze próby klasyfikowania podejścia do strategii należy datować na koniec lat osiemdziesiątych XX wieku. Można jednocześnie stwierdzić, że nadal trwa porządkowanie wiedzy o teorii strategii, a samo myślenie o strategii podlega ewolucji. A. Zakrzewska-Bielawska zebrała czternaście kryteriów klasyfikacji, według których publicyści naukowi starali się opisać szkoły i podejścia do strategii (Zakrzewska-Bielawska, 2014). J. Niemczyk w monografii poświęconej podejściu do strategii (Niemczyk, 2013) zaproponował kryterium, które A. Zakrzewska-Bielawska określiła jako „natura ludzka uczestników procesów decyzyjnych, jednostka analizy i jej kluczowe atrybuty, logika strategii (renta ekonomiczna) oraz akceptowalne strategie". Wydaje się, że intencją J. Niemczyka było przede wszystkim zaproponowanie klasyfikacji teorii strategii według kryterium renty ekonomicznej. Pojęcie renty ekonomicznej w ekonomii i naukach o zarządzaniu odnosi się do przedsiębiorstwa. W podręczniku do mikroekonomii (autorstwa D. Begga, S. Fischera i R. Dornbuscha) renta ekonomiczna określana jest jako „dodatkowa wypłata, jaką otrzymuje dany czynnik produkcji, ponad dochód transferowy konieczny do skłonienia go do świadczenia swych usług właśnie w tym zastosowaniu" (za: Światowiec-Szczepańska, 2012, s. 203-226). J. Niemczyk definicji renty ekonomicznej poświęca jedno zdanie: „Renta ekonomiczna to zysk przedsiębiorcy ponad koszt zaangażowanego kapitału" (Niemczyk, 2013, s. 26). 
Mimo wyraźnych konotacji renty ekonomicznej z językiem biznesu można stosunkowo łatwo przetransferować ją do aparatu pojęciowego sektora publicznego (konkretnie gminy), jeśli pod „zysk” podstawi się „korzyść społeczną”, a pod „zaangażowany kapitał” przedsiębiorcy - „zaangażowane zasoby” gminy. Administracja publiczna, podobnie jak przedsiębiorca, stara się tak gospodarować własnymi zasobami, aby uzyskać nadwyżkę w postaci dodatkowych korzyści z tych zasobów ponad ich zwykły koszt alternatywny. Grunt gminny, który stanowi jeden z najważniejszych składników mienia komunalnego, staje się źródłem renty ekonomicznej, jeśli w wyniku procedur administracyjnych i budowy infrastruktury liniowej oraz ze względu na atrakcyjną lokalizację zostaje przeznaczony pod inwestycje przemysłowe. Nietrudno się przekonać, że renta ekonomiczna jako kryterium klasyfikacji podejścia do strategii ma ogromny potencjał do konstruowania teorii strategii w sposób preskryptywny, a takiej wiedzy oczekują władze publiczne, którym powierzono odpowiedzialne zadanie zarządzania wspólnotami samorządowymi.

J. Niemczyk wyodrębnił pięć podejść do strategii. Trzy pierwsze: planistyczne, pozycyjne i zasobowe, zaklasyfikował do podejść klasycznych, a dwa kolejne: innowacyjno-przedsiębiorcze i sieciowe - do współczesnych (Niemczyk, 2014, s. 67-75). Wszystkie te podejścia zostaną wykorzystane w niniejszych badaniach.

Początek myślenia o strategii w polskich gminach należy właściwie datować na okres przemiany ustrojowej. T. Markowski wiąże „przyspieszenie” opracowywania strategii rozwoju przez samorząd terytorialny w Polsce z pojawieniem się w latach dziewięćdziesiątych XX wieku zachodnich konsultantów (Markowski, 1999, s. 197). Prawdziwy boom w planowaniu strategicznym nastapił jednak po przystapieniu Polski do Unii Europejskiej w 2004 r. wraz z uzyskaniem dostępu do funduszy strukturalnych. Posiadanie spisanej strategii rozwoju było zalecane przez instytucje zarządzające środkami Unii Europejskiej jednostkom samorządu, które starały się o pozyskanie funduszy unijnych. Wówczas niemal wszystkie gminy zrozumiały, że w ich czysto merkantylnym interesie jest opracowanie strategii rozwoju. Jeśli zatem początek myślenia o strategii w polskich gminach umieścić na początku XXI wieku, to trzeba zdać sobie sprawę, że nie będziemy mieli do czynienia $\mathrm{z}$ analogicznym jak w przypadku przedsiębiorstw chronologicznym podziałem podejść do strategii w gminach polskich. Klasyczne teorie strategii przedsiębiorstw były już dobrze rozwinięte na początku XXI wieku, zatem gminy mogły je zaadaptować „w pakiecie”, bez konieczności przechodzenia od jednej do drugiej. Współczesne teorie (podejścia innowacyjno-przedsiębiorcze i sieciowe) mogły migrować już w czasie rzeczywistym od przedsiębiorstw do samorządów.

Podejście planistyczne uważane jest za najbardziej tradycyjne wśród wszystkich teorii strategii. Jego założenia J. Niemczyk streścił w oparciu o kryterium renty ekonomicznej, dzięki czemu udało się naświetlić wiele jego cech. Szczególnie eksponowanym wyróżnikiem podejścia planistycznego jest nastawienie przedsiębiorstw na tworzenie sformalizowanych długoterminowych planów zawierających kierunki 
działań, cele, szczegółowe zadania, jakie zamierza podjąć firma. K. Obłój skupił się na tym aspekcie teorii planistycznej, omawiając przykłady dużych korporacji, które od lat pięćdziesiątych do siedemdziesiątych XX wieku swoją dominację budowały dzięki dużemu zaangażowaniu w planowanie i zarządzanie strategiczne (Obłój, 2014). Tworzenie planów strategicznych miało pozwalać firmom na kształtowanie przyszłości w racjonalny i uporządkowany sposób (Obłój, 2014, s. 27). Wyróżnikami będącymi pochodnymi głównego założenia podejścia planistycznego były twierdzenia, że w tworzeniu strategii liczy się przede wszystkim perspektywa prezesa firmy utożsamianego z głównym strategiem (Obłój, 2014, s. 29), a budowanie strategii jest sformalizowanym procesem, w którego efekcie miał powstać dokument spisana strategia rozwoju (Obłój, 2014, s. 30-33).

Ujęcie planistyczne wydaje się najbardziej naturalnym podejściem do strategii w gminie. R. Brol w opracowaniu Ekonomika i zarzqdzanie miastem stwierdza „Przeświadczenie, że każdy rodzaj planowania jest produktem minionej epoki, okazuje się błędne. To właśnie zmiana orientacji gospodarki z centralnie planowanej i zarządzanej na gospodarkę rynkową oraz decentralizacja państwa, znajdująca swój wyraz w reaktywowaniu samorządów lokalnych, stwarzają możliwość zastąpienia centralnego planowania dyrektywnego przez oddolne, terytorialne planowanie strategiczne, możliwe do zastosowania jedynie w warunkach demokratyczno-samorządowego modelu ustroju gminy" (Brol, 2004, s. 207). Praca pod redakcją R. Brola została wydana w 2004 r. Z tą datą należy wiązać wzrost zainteresowania gmin planowaniem strategicznym i konkretnie opracowaniem strategii rozwoju. A.P. Wiatrak rozróżnia cztery fazy podejścia samorządów do planowania strategicznego po 1990 r., a mianowicie: 1) lata 1990-1995 - małe zainteresowanie strategiami, 2) lata 1995-2000 - wzrost zainteresowania strategiami, początkowo jako narzędziem budowania wizerunku, 3) lata 2000-2005 - upowszechnienie przygotowania strategii rozwojowych, 4) od 2005 r. - integracja w ramach planowania strategicznego poszczególnych rodzajów planów danego obszaru oraz procedur monitorowania i badań ewaluacyjnych (Wiatrak, 2014, s. 677). Przystapienie Polski do Unii Europejskiej wiązało się z uruchomieniem finansowania projektów gminnych za pomocą funduszy strukturalnych i Funduszu Spójności. Opracowanie strategii rozwoju stało się zaleceniem, a opracowanie programu rozwoju lokalnego było obligatoryjne dla tych gmin, które zamierzały się ubiegać o finansowanie ze środków UE. Przed rokiem 2004 wiele strategii rozwoju zostało opracowanych przy współfinansowaniu ze środków tzw. przedakcesyjnych, jednak to właśnie z przystąpieniem Polski do Unii Europejskiej należy kojarzyć największy przyrost sformalizowanych strategii rozwoju gmin. Nastawienie jednostek samorządu terytorialnego do opracowywania dokumentów strategicznych nie jest związane wyłącznie z ogólną strategią rozwoju. Obecnie na półkach w urzędach gmin można odnaleźć wiele dokumentów strategicznych, których opracowanie wymagane jest przepisami prawa. W celu zobrazowania, jak intensywnie samorządy gminne angażowane są $\mathrm{w}$ planowanie strategiczne, można wymienić programy należące do 
zestawu obowiązkowych ${ }^{2}$ : program gospodarowania mieszkaniowym zasobem gminy, program opieki nad zabytkami, plan zrównoważonego rozwoju publicznego transportu zbiorowego, wieloletni plan rozwoju i modernizacji urządzeń wodociągowych i kanalizacyjnych, program ochrony środowiska, strategię integracji i rozwiązywania problemów społecznych, gminny program wspierania rodziny, program profilaktyki i rozwiązywania problemów alkoholowych, program przeciwdziałania narkomanii, program współpracy z organizacjami pozarządowymi. Do tego zestawu można by dołożyć wiele innych programów wymaganych przy pozyskiwaniu funduszy unijnych (np. program rewitalizacji, plan gospodarki niskoemisyjnej), a także fundamentalny dla planowania przestrzennego - studium uwarunkowań i kierunków zagospodarowania przestrzennego. Strategia rozwoju pod nazwą ,strategia rozwoju” nie jest dokumentem wymaganym przepisami, jednak jej bardzo bliski odpowiednik już tak. Jest to program rozwoju opracowywany na podstawie Ustawy z dnia 6 grudnia $2006 \mathrm{r}$. o zasadach prowadzenia polityki rozwoju ${ }^{3}$. Zgodnie $\mathrm{z}$ art. 17 tejże ustawy program rozwoju powinien określać: diagnozę sytuacji społeczno-gospodarczej w odniesieniu do zakresu objętego programowaniem strategicznym, cel główny i cele szczegółowe, priorytety oraz kierunki interwencji w zakresie terytorialnym, sposób monitorowania i oceny stopnia osiągania celu głównego i celów szczegółowych, plan finansowy, podstawowe założenia systemu realizacji. Strategia, która zawiera te elementy, może być uznawana za program rozwoju.

Podejście pozycyjne do strategii przewartościowało otoczenie organizacji. Chcąc określić swoją strategię w ujęciu pozycyjnym, przedsiębiorstwo powinno dobrze zdefiniować konkurenta. Konkurent jest punktem odniesienia, a analiza zasobów własnych i plan rozwoju tych zasobów bez wizji konkurenta tracą na znaczeniu. Renta ekonomiczna związana z podejściem pozycyjnym to renta chamberlinowska, której istota sprowadza się do tego, że przedsiębiorstwo, uwzględniając dynamikę sektora i prowadząc grę z konkurencją, osiaga większe korzyści z tytułu uprzywilejowanego miejsca w sektorze, niż osiagnęłoby, biorąc pod uwagę tylko potencjalną produktywność (Niemczyk, 2013, s. 98).

W przeciwieństwie do planistycznej koncepcji strategii podejście pozycyjne wydaje się odległe od natury gminy. Strategia według podejścia pozycyjnego ma charakter biznesowy. Teoria pozycyjna posługuje się pojęciami stricte ze świata przedsiębiorstw - konkurencja, dostawcy, odbiorcy, strategia niskich kosztów. Nie należy jednak przesądzać na tej podstawie, że podejście to nie może być zastosowane przez gminę. Przede wszystkim warto się zastanowić, w jakim zakresie i z kim gmina podejmuje konkurencję. Rozważaną tu sytuacją jest konkurencja między gminami.

${ }^{2}$ To, że nie wszystkie są opracowywane przez gminy, wynika często z braku norm sankcjonujących.

${ }^{3}$ Obowiązek uchwalania przez gminy programu rozwoju wynika ze zmiany ustawy o zasadach prowadzenia polityki rozwoju z $2014 \mathrm{r}$. 
A. Szromnik, zajmujący się w działalności naukowej m.in. marketingiem terytorialnym, wskazuje, że dla rozwoju gmin niezbędny jest dopływ kapitału finansowego, technologii, elementów rzeczowych, siły roboczej oraz informacji (Szromnik, 2011, s. 32). Gmina musi zatem podjąć określone działania, aby pozyskać te czynniki. Jest oczywiście w stanie w części wytworzyć je sama. Można przyjać założenie, że większe jednostki mogą tworzyć gospodarcze układy zamknięte, jednak nie ulega również wątpliwości, że gminy będą poszukiwać tych czynników na zewnątrz, czyli w innych gminach. Według T. Markowskiego gminę można postrzegać jako megaprodukt. Badacz stwierdził, że ,przez miasto jako megaprodukt rozumiemy wzajemnie powiązaną i ustrukturalizowaną formę produktów materialnych i niematerialnych (usług), dostępnych w mieście dla różnych jego użytkowników, które przy okazji konsumpcji poszczególnych produktów pozwalają na uzyskanie dodatkowej korzyści” (Markowski, 1999, s. 224-225). W takim podejściu można założyć, że gmina jest podmiotem aktywnie działającym na rynku, a jednocześnie w całości jest produktem rynkowym. A. Szromnik podkreśla, że zewnętrzne rynki docelowe jednostek samorządu terytorialnego to inne jednostki terytorialne dysponujące zasobami czynników wytwórczych, które można przemieścić (Szromnik, 2011, s. 32). Nośnikami tych zasobów są przede wszystkim mieszkańcy innych gmin, przedsiębiorstwa, podmioty z innych sektorów (np. pozarządowego) i turyści. W. Dziemianowicz dodaje jeszcze jedną płaszczyznę rywalizacji gmin środki zewnętrzne (za: Pytlak, 2010, s. 404). Szczegółowe czynniki konkurencyjności gmin możemy odnaleźć w pracach (Pytlak, 2010, s. 409-410; Szaja, 2013, s. 279-280).

Biorąc pod uwagę przedstawione rozważania, można stwierdzić, że gmina w ujęciu pozycyjnym będzie nastawiona na otoczenie, szczególnie na to, w którym znajduje się jej konkurent, czyli inna gmina.

W podejściu zasobowym, które dominowało na przełomie XX i XXI wieku (Niemczyk, 2013, s. 106), przedsiębiorca ponownie kieruje uwagę na wnętrze organizacji i zasoby własne. Z przeniesieniem pojęć podejścia zasobowego na grunt jednostki samorządu terytorialnego nie jest tak trudno jak w przypadku ujęcia pozycyjnego. Gmina w podejściu zasobowym, podobnie jak w planistycznym, będzie skoncentrowana na czynnikach wewnętrznych i zasobach własnych, zarówno na ich analizowaniu na poziomie diagnozy, jak i na ich rozwijaniu w części postulatywnej. J. Niemczyk podkreślił różnice obu ujęć (Niemczyk, 2013, s. 108). W ujęciu planistycznym liczyły się przede wszystkim czynniki produkcji i kapitał finansowy, w ujęciu zasobowym na znaczeniu zyskują kompetencje pracowników, know-how firmy i jego kadry, marka przedsiębiorstwa, wartość dla akcjonariuszy, umiejętność realizacji usługi w sposób trudny do imitowania, relacje pracownicze itd. W literaturze przedmiotu można wychwycić treści, w których badacze, z zamiarem również edukacyjnym, dostrzegają konieczność przewartościowania zasobów własnych jednostek samorządu terytorialnego prowadzących politykę rozwoju. M.W. Kozak podkreśla w swoich publikacjach, że zarówno rząd, jak i samorządy są głuche na 
zalecenia akademików i teorie rozwoju innowacji, sieci współpracy czy rozwoju kapitału społecznego powstałe na przełomie XX i XXI wieku, nadal zorientowane są na finansowanie infrastruktury i marginalizują niematerialne czynniki rozwoju. W artykule Konflikty wokót nowego paradygmatu a rozwój regionalny Polski po 1990 roku (Kozak, 2014), który powstał na kanwie referatu wygłoszonego 11 czerwca 2013 r. przez badacza podczas konferencji „Gospodarka Polski 1990-2013” w Krakowie, M.W. Kozak podaje dane, z których wynika, że ok. 70\% środków europejskich w Polsce przeznaczanych jest na infrastrukturę, co raczej przybliża nas do ścieżki rozwojowej Grecji, a oddala od modelu rozwoju np. Irlandii. Porównując teorie nowej i starej ery, Kozak stosuje opozycję czynników rozwojowych twardych, wśród których wymienia głównie infrastrukturę, i miękkich, takich jak: kapitał ludzki i społeczny, kultura, instytucje, sieci (Kozak, 2014, s. 139). Warto się zastanowić, jakie jeszcze czynniki miękkie lub inaczej niematerialne w nowym ujęciu, które, jak można łatwo zauważyć, zawiera wiele postulatów podejścia zasobowego, będą kluczowe w rozwoju lokalnym. Wymieniony już kapitał ludzki, który zgodnie z klasyfikacją H. Króla obejmuje wiedzę, umiejętności, zdolności, zdrowie, motywację, postawy, wartości, jako zasób w przypadku gminy będzie się odnosił zarówno do pracowników administracji samorządowej, jak i do ogółu mieszkańców gminy w podziale na różne grupy społeczne, a także do pracowników przedsiębiorstw i innych podmiotów. Rozwój kapitału strukturalnego w gminie będzie dotyczył jednostek organizacyjnych gminy i ich czynników świadczenia usług. Bardzo szczegółową klasyfikację instrumentów lokalnej polityki gospodarczej przeprowadził A. Sztando. Wymienił wśród nich m.in. edukacyjne instrumenty stymulacji rozwoju lokalnej przedsiębiorczości, w tym np. instrumenty edukacji bezpośredniej (szkolenia, doradztwo ekonomiczne, porady prawne) oraz instrumenty wspomagania podmiotów oświatowych, naukowych, badawczo-rozwojowych (Sztando, 2004, s. 153). Kapitał relacji zewnętrznych, jako zasób niematerialny gminy, odnosi się również przede wszystkim do jednostek organizacyjnych własnych. Wśród zasobów niematerialnych gminy należy wymienić markę gminy, jej tożsamość kulturową, wizerunek. Szczególnie marka, jako ważna wartość w ujęciu zasobowym, może być przedmiotem analiz i postulatów gminy. Jak pisze, za A. Szromnikiem, A. Waligóra: „to, co łączy miasto (jednostkę osadniczą) jako markę - produkt z innymi podmiotami marketingowej analizy, to kompleksowy wielowymiarowy obraz ukształtowany $\mathrm{w}$ wyniku długotrwałego, planowego i racjonalnego działania polegającego na przekonywaniu i upowszechnianiu w otoczeniu jego charakterystycznych cech, właściwości i funkcji” (Waligóra, 2015, s. 252).

Podejście innowacyjne dookreślone jest przez J. Niemczyka jako innowacyjno-przedsiębiorcze. Wspomniany autor uważa je za jedno ze współczesnych podejść, które zaczęto stosować wraz z XXI wiekiem i które odgrywa obecnie kluczową rolę w gospodarce. Trudno właściwie wyobrazić sobie, aby w najbliższym czasie miał nastąpić kres przekonania, że „czerpanie dochodu z ponadprzeciętnej aktywności osób, skierowanej przede wszystkim na poszukiwanie nowych rozwiązań w bizne- 
sie"4 jest warunkiem sukcesu gospodarczego. Przedsiębiorca działający zgodnie z ideą renty innowacyjno-przedsiębiorczej nie skupia się na doskonaleniu stanów zastanych, lecz na twórczej destrukcji istniejącego porządku i budowaniu rozwiązań typu blue ocean (Niemczyk, 2013, s. 132). Jego uwaga będzie skierowana na zewnątrz organizacji. W otoczeniu będzie poszukiwał informacji, na których oprze strategię. K. Obłój podkreślał, że otoczenie w ujęciu innowacyjnym postrzegane jest przede wszystkim jako szansa (Obłój, 2014, s. 120).

Potrzeba kreowania innowacji bardzo łatwo upowszechniła się w sektorze publicznym. Na szczególną uwagę zasługuje idea smart city. Odniesienie w tytule do miasta nie ma szczególnego znaczenia. Koncepcja smart city teoretycznie dotyczyć może także gminy wiejskiej. D. Stawasz i D. Sikora-Fernandez w artykule Koncepcja smart city a zarządzanie miastem omawiają podejście smart do zarządzania usługami publicznymi i ogólnie jednostką terytorialną (Stawasz i Sikora-Fernandez, 2016). Badaczki objaśniają, że działając zgodnie z podejściem smart city, gmina ma na celu ograniczenie zużycia zasobów, realizację usług na wyższym poziomie i tworzenie lepszych warunków rozwoju działalności gospodarczej. Wskazują, że ma to być osiaggane dzięki wykorzystaniu technik ITC, co należy jednak potraktować jako niepotrzebne zawężenie operacjonalizacji idei smart city. W Wikipedii hasło smart city funkcjonuje jako ,inteligentne miasto”, za twórcę tego określenia uznawany jest B. Cohen z Universidad del Desarrollo w Santiago de Chile (Inteligentne miasto, b.d.). Wracając do wniosków przedstawionych przez D. Stawasz i D. Sikorę-Fernandez, badaczki są przekonane, że gmina, która stosuje nowoczesne technologie do usprawniania usług publicznych, oddziałuje tym samym na struktury miejskie. W konsekwencji ma to pozytywny wpływ na zachowania mieszkańców i przedsiębiorców. Za N. Komninosem, R. Hollandsem i P. Lombardi Stawasz i Sikora-Fernandez proponują następującą definicję inteligentnego miasta: „terytorium o wysokiej zdolności uczenia się i innowacji, kreatywne, mające instytucje badawcze i rozwojowe, szkolnictwo wyższe, koncentrujące się na wykorzystaniu infrastruktury transportowej i telekomunikacyjnej, ICT, cyfrowych mediów oraz posiadające wykształconych obywateli, wykorzystujące nowe kanały komunikacji między administracją lokalną a obywatelami” (Stawasz i Sikora-Fernandez, 2016, s. 76). Być może nie można dostrzec w tej definicji pierwiastka schumpeteriańskiej destrukcji czy strategii blue ocean, jednak nie należy się spodziewać, aby gmina $\mathrm{z}$ całym bagażem ograniczeń była w stanie w pełni odzwierciedlić w swoim podejściu do strategii wszystkie elementy ujęcia innowacyjnego. Należy raczej przypuszczać, że przejmowanie koncepcji konkurowania innowacyjnością będzie następowało po trochu, wybiórczo i ostrożnie.

Podejście sieciowe również zostało przez J. Niemczyka zakwalifikowane do współczesnych podejść do strategii. Zasadniczą przesłanką do tworzenia sieci jest

${ }^{4}$ Tak właśnie J. Niemczyk definiuje rentę innowacyjno-przedsiębiorczą, zob. (Niemczyk, 2013, s. 125). 
optymalne z punktu widzenia interesariuszy zarządzanie kontraktami (Niemczyk, 2013, s. 141), ale funkcjonowanie w sieci kreuje rentę ekonomiczną (Niemczyk i Latocha, 2014), której samodzielnie, bez kooperantów w sieci międzyorganizacyjnej, przedsiębiorstwo nie jest w stanie osiagnąć. $Z$ tego też względu uwaga przedsiębiorstwa skierowana jest na zewnątrz. Na rentę ekonomiczną w ujęciu sieciowym składają się: nadwyżka z tytułu niższych kosztów transakcyjnych i niższych kosztów hierarchii, nadwyżka z tytułu tworzenia wartości w logice łańcucha, warsztatu lub sieci wartości, nadwyżka z tytułu apropriacji wartości powstającej u innych uczestników sieci, nadwyżka z tytułu sieciowego tworzenia i dyfuzji w sieci wiedzy niejawnej, efekt sieciowy (Niemczyk i Latocha, 2014, s. 146). Korzyści, które uzyskuje organizacja w sieci, jest wiele. Są one w literaturze przedmiotu szeroko omawiane.

$\mathrm{Z}$ renty sieciowej mogą korzystać jednostki samorządu terytorialnego. To, że gminy pod względem zadań i sposobu realizacji usług publicznych wynikających z przepisów prawa, struktury organizacyjnej i struktury majątku są niemalże kopiami, czyni je, przynajmniej teoretycznie, idealnymi partnerami do współpracy. W pewnym zakresie współpraca ta może nabrać znamion sieci kooperantów (np. budowanie centrów usług wspólnych, przystępowanie do spółek celowych, organizacja transportu). Kooperacja między gminami będzie miała zawsze charakter horyzontalny. M. Furmankiewicz za innymi badaczami wymienia przesłanki skłaniające gminy do współpracy: 1) formalnoprawne (np. wspólne gospodarowanie majątkiem w związkach komunalnych), 2) ekonomiczno-finansowe wynikające z przekonania, że wspólnie można wykonać zadanie taniej, 3) prakseologiczne wynikające z przekonania, że poprawi to organizację pracy (np. wzajemna pomoc w przygotowaniu dokumentów legislacyjnych), 4) ekologiczne wynikające z braku możliwości rozwiązania problemów ekologicznych w izolacji, 5) społeczno-kulturalne dotyczące nawiązywania kontaktów międzyludzkich, 6) polityczne związane np. z przynależnością do organizacji krajowych i międzynarodowych (Furmankiewicz, 2002, s. 9-10). Należałoby dodać do tej klasyfikacji przesłanki wynikające wprost z potrzeby wzmocnienia konkurencyjności gmin tworzących sieć. Taki przypadek może zajść szczególnie w układach powiązań funkcjonalno-przestrzennych, do których należy zaliczyć m.in. aglomeracje najsilniej reprezentowane przez miejskie obszary funkcjonalne stolic województw. Delimitację tych obszarów przeprowadził P. Śleszyński (2013). Legła ona u podstaw krajowej polityki spójności na lata 2014-2020, zgodnie z którą miejskie obszary funkcjonalne otrzymały osobną pulę środków unijnych jako główne ośrodki wzrostu. Cele polityki spójności w tym obszarze dotyczyły budowania silnych powiązań sieciowych gmin tworzących aglomeracje miast wojewódzkich i subregionalnych. Powiązania te miały być wzmacniane m.in. poprzez opracowywanie strategii rozwoju obszarów funkcjonalnych i strategii zintegrowanych inwestycji terytorialnych, a także, co najważniejsze, poprzez realizację wspólnych przedsięwzięć w dziedzinie transportu, rewitalizacji, poprawy stanu śro- 
dowiska przyrodniczego, efektywności energetycznej, rozwoju funkcji symbolicznych oraz wzmacniania badań, rozwoju technologicznego i innowacji (Zintegrowane Inwestycje Terytorialne, b.d.).

Powiązania między jednostkami samorządu terytorialnego a innymi podmiotami, np. z sektora prywatnego, wyższych uczelni, organizacji pozarządowych, zrzeszeń przedsiębiorców, mogą wystąpić np. w klastrach, w które zaangażowane są jednostki terytorialne, a także w ogólnej koncepcji delegowania wykonywania zadań publicznych do sektora prywatnego, w tym przedsiębiorstw i organizacji non profit. A. Chrisidu-Budnik w artykule Administracja publiczna w strukturze sieciowej wymienia dwie płaszczyzny obecności administracji publicznej w strukturach sieciowych (Chrisidu-Budnik, 2009). Pierwsza odnosi się do zaangażowania władz publicznych w sieć. Występując w roli aktywnej, administracja publiczna m.in. inicjuje utworzenie sieci czy pełni funkcje brokera sieci (jak dzieje się np. w wypadku niektórych inicjatyw klastrowych). W drugiej płaszczyźnie władza publiczna poszukuje organizacji sieciowej (inaczej nazywanej heterarchiczną) alternatywnej wobec organizacji hierarchicznej.

Należy się spodziewać, że gmina, której bliskie będzie podejście sieciowe, na poziomie analizy strategicznej skoncentruje się na środowisku zewnętrznym, wyszukując w nim partnerów do działania sieciowego oraz szanse efektywnej realizacji zadań publicznych. W diagnozie powinien więc zostać przeanalizowany zasób relacyjny gminy, w tym dotychczasowi partnerzy, siła relacji, zakres potencjalnej współpracy. Wśród postulatów z kolei powinny się znaleźć cele dotyczące budowy zasobów relacyjnych.

Jednostki samorządu terytorialnego jako organizacje ze względu na swoje funkcje oraz sposób działania mogą absorbować elementy podejścia planistycznego, pozycyjnego, zasobowego, innowacyjnego i sieciowego, włączając je do swoich strategii. W wypadku przedsiębiorstw, do których literatura przedmiotu odnosi klasyfikacje teorii strategii, wybór strategii, modelu biznesu i tym samym renty ekonomicznej może być zdecydowany i ograniczony do jednego podejścia. Należy jednak wziąć pod uwagę, że w przedsiębiorstwach, a szczególnie w jednostkach samorządu terytorialnego, jedno podejście nie zastępuje zupełnie innego, tak więc wybrane ujęcie strategii może dominować, ale nie wyczerpuje 100\% tworzenia strategii. Dokonuje się przewartościowanie pewnych czynników rozwojowych, jedno podejście przeważa nad innymi, których cechy pojawiają się, choć z mniejszą siłą. Można zaryzykować, nieco wbrew przejrzystej chronologii rozwoju podejść zaprezentowanej przez takich autorów, jak J. Niemczyk i K. Obłój, że obecnie wiele funkcjonujących organizacji przejawia cechy każdego z opisanych podejść do strategii równocześnie lub na różnych etapach swojego rozwoju. $Z$ pewnością takie zjawisko możemy zaobserwować w jednostkach samorządu terytorialnego. Badania empiryczne zostały poświęcone ocenie, z jaką siłą wyróżniki każdego z pięciu podejść do strategii występują w spisanych strategiach rozwoju gmin. 


\section{Postępowanie badawcze w odniesieniu do strategii gmin w Polsce}

Podstawową przyjętą metodą badawczą była analiza treści dokumentów źródłowych, do których należą strategie rozwoju spisane i uchwalone przez rady gminne. Składa się na nią analiza zapisów uznanych przez autorów strategii kluczowych wniosków z diagnozy i analizy SWOT oraz postulatów przyjętych w procesie opracowywania strategii. Ważny argument, który stoi za wyborem jako wiodącej metody badawczej analizy treści strategii, jest taki, że powstanie strategii gminy to proces angażujący co do zasady wszystkich interesariuszy, a także podmioty odpowiedzialne za zarządzanie majątkiem gminy i innymi jej zasobami. Opracowanie strategii jest procesem długim, podczas którego zawsze występują konsultacje społeczne, a zatem ma walor dokumentu uzgodnionego przez władzę uchwałodawczą, wykonawczą i przez interesariuszy. Analiza treści strategii powinna zatem odkryć podejście do strategii, jakim kierują się wszyscy reprezentujący gminę. Do badania włączono dodatkową metodę, której celem jest weryfikacja wniosków z analizy treści strategii dokonana przez ekspertów odpowiedzialnych są za planowanie strategiczne w samorządach gminnych. Przeprowadzono pięć wywiadów pogłębionych z osobami piastującymi minimum przez 10 lat kierownicze stanowiska w komórkach urzędów gmin odpowiedzialnych za opracowanie i wdrażanie strategii rozwoju. Osoby te ze względu na doświadczenie uznano za ekspertów w dziedzinie planowania strategicznego w administracji samorządowej.

Strategie, które uwzględniono w analizie treści, zostały uchwalone przez rady gminne i są dostępne na oficjalnych stronach internetowych, głównie w biuletynach informacji publicznej. Na potrzeby analizy treści każdej strategii podzielono je na trzy części (z niewielkimi odstępstwami, gdy danej części nie było - chodzi o analizę SWOT): analizę strategiczną (diagnozę), analizę SWOT oraz część postulatywną (programowa) strategii.

Analiza SWOT, zgodnie z zaleceniami literaturowymi ${ }^{5}$, stanowi przejście pomiędzy analizą strategiczną i częścią postulatywną. Zazwyczaj jest wyodrębnioną częścią strategii, a jej zapisy, choć powinny bezpośrednio nawiązywać do diagnozy i wskazywać wstępne kierunki rozwoju, są de facto katalogiem wniosków, które nie pochodzą z żadnej innej części strategii. W rzeczywistości jest to mankament metodyczny wielu strategii, ale na potrzeby niniejszych badań uwzględnia się treści zawarte w analizie SWOT jako istotny materiał źródłowy. Najczęściej analiza SWOT jest przedstawiona w formie tabeli - macierzy podzielonej na cztery części według czynników rozwojowych, tj. mocne i słabe strony oraz szanse i zagrożenia. Najczęściej również, prócz identyfikacji czynników rozwojowych w postaci haseł, nie zawiera innych elementów. Rzadko czynnikom rozwojowym przypisuje się wagi i równie rzadko przeprowadzane są korelacje czynników rozwojowych, z których wnioski są wstępem do określenia kierunków rozwoju.

5 Zgodnie z terminologią to analiza TOWS/SWOT. Opis metody np. w (Obłój, 2014, s. 279-300). 
Każda z wyszczególnionych części strategii była analizowana odrębnie. Badając strategie gmin, podjęto się analizy czterech jej cech związanych z podejściami do strategii, sformułowanych w postaci pytań, którym przyporządkowano kafeterię odpowiedzi. Każdy element kafeterii jest tożsamy z wyróżnikiem (cechą) pięciu podejść do strategii wyodrębnionych na etapie badań literaturowych. Występowanie danej cechy - wyróżnika - było oceniane w pięciostopniowej skali, a także opisane $\mathrm{w}$ formie krótkiego uzasadnienia (recenzji). Im większe było nasilenie występowania danej cechy, tym wyższą ocenę przypisano.

Pytanie 1. W jakim stopniu analiza strategiczna koncentruje się na czynnikach wewnętrznych, a w jakim na czynnikach zewnętrznych?

Tabela 1. Wyróżniki podejścia do strategii w odniesieniu do stopnia koncentracji analizy strategicznej na czynnikach wewnętrznych i czynnikach zewnętrznych

\begin{tabular}{|l|l|l|l|l|l|}
\hline \multicolumn{1}{|c|}{ Podejście } & \multicolumn{1}{c|}{ Planistyczne } & \multicolumn{1}{c|}{ Pozycyjne } & \multicolumn{1}{c|}{ Zasobowe } & Innowacyjne & \multicolumn{1}{c|}{ Sieciowe } \\
\hline Kafeteria & analiza & analiza & analiza & analiza & analiza \\
odpowiedzi - & strategiczna & strategiczna & strategiczna & strategiczna & strategiczna \\
wyróżniki & koncentruje się & koncentruje & koncentruje się & koncentruje & koncentruje \\
& na czynnikach & się na & na czynnikach & się na & się na \\
& wewnętrznych & czynnikach & wewnętrznych & czynnikach & czynnikach \\
& & zewnętrznych & & zewnętrznych & zewnętrznych \\
\hline
\end{tabular}

Źródło: opracowanie własne.

Pytanie 2. Na jakich zasobach koncentruje się analiza strategiczna?

Tabela 2. Wyróżniki podejścia do strategii w odniesieniu do zasobów, na jakich koncentruje się analiza strategiczna

\begin{tabular}{|c|c|c|c|c|c|}
\hline Podejście & Planistyczne & Pozycyjne & Zasobowe & Innowacyjne & Sieciowe \\
\hline $\begin{array}{l}\text { Kafeteria } \\
\text { odpowiedzi } \\
\text { - wyróżniki }\end{array}$ & $\begin{array}{l}\text { analiza } \\
\text { strategiczna } \\
\text { koncentruje } \\
\text { się na } \\
\text { zasobach } \\
\text { materialnych, } \\
\text { zasobach } \\
\text { biernych }\end{array}$ & $\begin{array}{l}\text { analiza } \\
\text { strategiczna } \\
\text { koncentruje się } \\
\text { na zasobach } \\
\text { odróżniających, } \\
\text { dostawcach } \\
\text { usług } \\
\text { publicznych, } \\
\text { odbiorcach usług } \\
\text { (ich potrzebach), } \\
\text { konkurencji }\end{array}$ & $\begin{array}{l}\text { analiza } \\
\text { strategiczna } \\
\text { koncentruje się } \\
\text { na zasobach } \\
\text { głównie } \\
\text { niematerialnych } \\
\text { i kompetencjach } \\
\text { mieszkańców, } \\
\text { instytucji } \\
\text { publicznych, } \\
\text { przedsiębiorstw, } \\
\text { zasobach } \\
\text { czynnych }\end{array}$ & $\begin{array}{l}\text { analiza } \\
\text { strategiczna } \\
\text { koncentruje } \\
\text { się na } \\
\text { zasobach } \\
\text { unikatowych } \\
\text { (posiadanych } \\
\text { innowacjach) }\end{array}$ & $\begin{array}{l}\text { analiza } \\
\text { strategiczna } \\
\text { koncentruje } \\
\text { się na } \\
\text { zasobach } \\
\text { relacyjnych, } \\
\text { powiązaniach } \\
\text { z innymi } \\
\text { gminami }\end{array}$ \\
\hline
\end{tabular}

Źródło: opracowanie własne. 
Pytanie 3. Na jakich czynnikach rozwojowych koncentrują się strategie budowane w oparciu o analizę SWOT?

Tabela 3. Wyróżniki podejścia do strategii w odniesieniu do czynników rozwojowych, na których koncentrują się strategie budowane w oparciu o analizę SWOT

\begin{tabular}{|l|l|l|l|l|l|}
\hline \multicolumn{1}{|c|}{ Podejście } & \multicolumn{1}{|c|}{ Planistyczne } & \multicolumn{1}{c|}{ Pozycyjne } & \multicolumn{1}{c|}{ Zasobowe } & \multicolumn{1}{c|}{ Innowacyjne } & \multicolumn{1}{c|}{ Sieciowe } \\
\hline $\begin{array}{l}\text { Kafeteria } \\
\text { odpowiedzi - } \\
\text { wyróżniki }\end{array}$ & $\begin{array}{l}\text { w analizie SWOT } \\
\text { budowane } \\
\text { strategie } \\
\text { koncentrują się } \\
\text { na SW }\end{array}$ & $\begin{array}{l}\text { w analizie SWOT } \\
\text { budowane } \\
\text { strategie } \\
\text { koncentrują się } \\
\text { na OT }\end{array}$ & $\begin{array}{l}\text { w analizie SWOT } \\
\text { budowane } \\
\text { strategie } \\
\text { koncentrują się } \\
\text { na SW }\end{array}$ & $\begin{array}{l}\text { w analizie SWOT } \\
\text { budowane } \\
\text { strategie } \\
\text { koncentrują się } \\
\text { na OT }\end{array}$ & $\begin{array}{l}\text { w analizie } \\
\text { SWOT } \\
\text { budowane } \\
\text { strategie } \\
\text { koncentrują się } \\
\text { na OT }\end{array}$ \\
\hline
\end{tabular}

Źródło: opracowanie własne.

Pytanie 4. Na jakich działaniach koncentruje się strategia w części postulatywnej? W jaki sposób buduje przewagę konkurencyjną?

Tabela 4. Wyróżniki podejścia do strategii w odniesieniu do sposobu budowania przewagi konkurencyjnej i podejmowanych działań

\begin{tabular}{|c|c|c|c|c|c|}
\hline Podejście & Planistyczne & Pozycyjne & Zasobowe & Innowacyjne & Sieciowe \\
\hline $\begin{array}{l}\text { Kafeteria } \\
\text { odpowiedzi - } \\
\text { wyróżniki }\end{array}$ & $\begin{array}{l}\text { postulaty } \\
\text { koncentrują się } \\
\text { na wykorzystaniu } \\
\text { własnych zasobów } \\
\text { materialnych } \\
\text { i lokalizacyjnych, } \\
\text { na osiąganiu } \\
\text { celów związanych } \\
\text { z pozyskaniem } \\
\text { inwestorów, } \\
\text { nowych } \\
\text { mieszkańców } \\
\text { i turystów }\end{array}$ & $\begin{array}{l}\text { postulaty } \\
\text { koncentrują się } \\
\text { na zwiększeniu } \\
\text { udziału w rynku, } \\
\text { poszukiwaniu } \\
\text { uprzywilejowanej } \\
\text { pozycji, na } \\
\text { konkurentach } \\
\text { i wyróżnianiu się }\end{array}$ & $\begin{array}{l}\text { postulaty } \\
\text { koncentrują się } \\
\text { na wykorzystaniu } \\
\text { własnych } \\
\text { zasobów, głównie } \\
\text { niematerialnych, } \\
\text { budowaniu marki, } \\
\text { kompetencji } \\
\text { stanowiących } \\
\text { wartość dla } \\
\text { mieszkańców } \\
\text { i obecnych } \\
\text { przedsiębiorców }\end{array}$ & $\begin{array}{l}\text { postulaty } \\
\text { koncentrują się } \\
\text { na stworzeniu, } \\
\text { wykreowaniu } \\
\text { innowacji }\end{array}$ & $\begin{array}{l}\text { postulaty } \\
\text { koncentrują się } \\
\text { na określeniu } \\
\text { swojej pozycji } \\
\text { w sieci } \\
\text { i wykorzystaniu } \\
\text { sieci w rozwoju }\end{array}$ \\
\hline
\end{tabular}

Źródło: opracowanie własne.

Ocena punktowa każdej strategii z podziałem na cztery pytania została wsparta krótkimi opisami w formie uzasadnienia (recenzji). W ujęciu chronologicznym procesu badawczego najpierw była wykonywana ocena opisowa, a następnie punktowa. Rolą opisów jest faktyczne uzasadnienie oceny punktowej, ale pełnią one również samodzielnie funkcję oceny jakościowej. Ze względu na obszerność oceny opisowej nie zamieszczono jej w artykule. Należy jednak zaznaczyć, że każda strategia została szczegółowo przeanalizowana pod względem zawartych w niej zapisów w analizie strategicznej, analizie SWOT i w części postulatywnej.

Do badania zostały wytypowane gminy według czterech kategorii. Podziału dokonano na podstawie klasyfikacji NUTS (Klasyfikacja NUTS..., b.d.), publikacji 
Delimitacja Miejskich Obszarów Funkcjonalnych stolic województw (Śleszyński, 2013) oraz Koncepcji Przestrzennego Zagospodarowania Kraju 2030 (Koncepcja Przestrzennego..., b.d.). Zgodnie z przyjętą i stosowaną w statystyce publicznej klasyfikacją NUTS kraj podzielony jest na pierwszym poziomie (NUTS 1) na 7 makroregionów: Południowy, Północno-Zachodni, Południowo-Zachodni, Północny, Centralny, Wschodni, Województwo Mazowieckie. To one, zgodnie z założeniem równomiernego rozkładu przestrzennego w skali kraju, stały się podstawową warstwą doboru gmin do badania. W obrębie każdego makroregionu losowo dobrano gminy w czterech kategoriach: 1) miasta - stolice regionów, 2) miasta - stolice subregionów, 3) gminy z obszarów funkcjonalnych dużych miast (gminy wchodzące w skład aglomeracji wielkomiejskich), 4) gminy leżące z dala od dużych ośrodków miejskich (peryferyjne). Gminy z obszarów funkcjonalnych zostały wytypowane na podstawie (Śleszyński, 2013), a gminy peryferyjne - na podstawie (Koncepcja Przestrzennego..., b.d.).

Należy wyjaśnić zastosowaną zasadę doboru gmin do badania. Przyjęto hipotezy, których zweryfikowanie ukaże zróżnicowanie pomiędzy gminami w podejściu do strategii. Główna hipoteza i dodatkowe hipotezy zostały zaprezentowane w części dotyczącej celów artykułu, warto jednak je przypomnieć. Pierwsza dodatkowa hipoteza zakłada, że miasta duże - stolice regionów będą bardziej zorientowane na podejście innowacyjne ze względu na swój potencjał kapitału ludzkiego (ludzie nauki). Druga hipoteza zakłada, że gminy aglomeracyjne będą bardziej zorientowane na podejście sieciowe ze względu na dużą wspólnotę interesów zarówno z rdzeniem aglomeracji, jak i z jego gminami satelitarnymi. Dobranie do próby miast - stolic subregionów ma za zadanie wprowadzenie metody kontrfaktycznej do weryfikacji pierwszej hipotezy. Miasta - stolice subregionów to średniej wielkości ośrodki miejskie, w których kapitał naukowy jest znacznie mniejszy. Pozostają one jednocześnie ośrodkami miejskimi o wielu funkcjach zbliżonych do funkcji stolic regionów. Z kolei dobranie do próby gmin peryferyjnych miało na celu włączenie do badań metody kontrfaktycznej w weryfikacji pierwszej i drugiej hipotezy. Mniejsze gminy peryferyjne pozostają z dala od dużych ośrodków miejskich, nie posiadają niemal w ogóle kapitału naukowego, nie mają również naturalnych warunków do budowania sieci, w każdym razie nie takich, jak gminy aglomeracyjne. Dobór próby odzwierciedla również gradację wielkości gmin objętych badaniem - od największych miast przez średnie do małych gmin wielkości co najwyżej stolic powiatów. Gminy aglomeracyjne to także mniejsze samorządy.

$\mathrm{W}$ tabeli 5 podano spis wszystkich gmin z określeniem rodzaju gminy oraz położenia według województw. W kolejnej tab. 6 podano tytuł dokumentu, który został objęty badaniem oraz numerem uchwały, którą rada danej gminy przyjęła strategię. Strategie gminne to obszerne opracowania, które formalnie stanowią załączniki do uchwał o ich przyjęciu. Dostępne są głównie w biuletynach informacji publicznej gmin. Badania przeprowadzono w okresie marzec-maj 2019 r., a strategie objęte badaniem były przyjmowane przez samorządy w latach 2011-2018. 
Tabela 5. Zestawienie gmin objętych badaniem preferowanego podejścia do strategii

\begin{tabular}{|c|c|c|c|}
\hline Gmina & Rodzaj gminy & Województwo & $\begin{array}{c}\text { Liczba ludności na } \\
\text { dzień } 31.12 .2017\end{array}$ \\
\hline \multicolumn{4}{|c|}{ Miasta - stolice regionów } \\
\hline Łódź & miejska & tódzkie & 690422 \\
\hline Wrocław & miejska & dolnośląskie & 638586 \\
\hline Kraków & miejska & małopolskie & 767348 \\
\hline Poznań & miejska & wielkopolskie & 538633 \\
\hline Gdańsk & miejska & pomorskie & 464254 \\
\hline Warszawa & miejska & mazowieckie & 1764615 \\
\hline Lublin & miejska & lubelskie & 339850 \\
\hline \multicolumn{4}{|c|}{ Miasta - stolice subregionów } \\
\hline Sandomierz & miejska & świętokrzyskie & 23863 \\
\hline Legnica & miejska & dolnośląskie & 100324 \\
\hline Częstochowa & miejska & śląskie & 224376 \\
\hline Koszalin & miejska & zachodniopomorskie & 107670 \\
\hline Grudziądz & miejska & kujawsko-pomorskie & 95629 \\
\hline Ciechanów & miejska & mazowieckie & 44303 \\
\hline Przemyśl & miejska & podkarpackie & 61808 \\
\hline \multicolumn{4}{|c|}{ Gminy aglomeracyjne } \\
\hline Zgierz & miejska & łódzkie & 56690 \\
\hline Kąty Wrocławskie & miejsko-wiejska & dolnośląskie & 24021 \\
\hline Liszki & wiejska & małopolskie & 17110 \\
\hline Swarzędz & miejsko-wiejska & wielkopolskie & 49727 \\
\hline Nowa Wieś Wielka & wiejska & kujawsko-pomorskie & 10030 \\
\hline Piaseczno & miejsko-wiejska & mazowieckie & 82526 \\
\hline Choroszcz & miejsko-wiejska & podlaskie & 14967 \\
\hline \multicolumn{4}{|c|}{ Gminy peryferyjne } \\
\hline Staszów & miejsko-wiejska & świętokrzyskie & 25897 \\
\hline Lwówek Śląski & miejsko-wiejska & dolnośląskie & 17346 \\
\hline Gorlice & wiejska & małopolskie & 17183 \\
\hline Okonek & miejsko-wiejska & wielkopolskie & 8691 \\
\hline Giżycko & miejska & warmińsko-mazurskie & 29480 \\
\hline Przysucha & miejsko-wiejska & mazowieckie & 12027 \\
\hline Tyszowce & miejsko-wiejska & lubelskie & 5665 \\
\hline
\end{tabular}

Źródło: opracowanie własne na podstawie (Główny Urząd Statystyczny, b.d.). 
Tabela 6. Dokumenty źródłowe objęte badaniem preferowanego podejścia do strategii w badanych gminach

\begin{tabular}{|c|c|c|}
\hline Gmina & Dokument źródłowy & Uchwała przyjmująca \\
\hline 1 & 2 & 3 \\
\hline \multicolumn{3}{|c|}{ Miasta - stolice regionów } \\
\hline Łódź & $\begin{array}{l}\text { Strategia Zintegrowanego } \\
\text { Rozwoju Łodzi } 2020+\end{array}$ & $\begin{array}{l}\text { Uchwała nr XLIII/824/12 Rady Miejskiej } \\
\text { w Łodzi z dnia } 25 \text { czerwca } 2012 \text { r. }\end{array}$ \\
\hline Wrocław & Strategia Wrocław 2030 & $\begin{array}{l}\text { Uchwała nr LI/1193/18 Rady Miejskiej } \\
\text { Wrocławia z dnia } 15 \text { lutego } 2018 \text { r. }\end{array}$ \\
\hline Kraków & $\begin{array}{l}\text { Strategia Rozwoju Krakowa. Tu } \\
\text { chcę żyć. Kraków } 2030\end{array}$ & $\begin{array}{l}\text { Uchwała nr XCIV/2449/18 Rady Miasta } \\
\text { Krakowa z dnia } 7 \text { lutego } 2018 \text { r. }\end{array}$ \\
\hline Poznań & $\begin{array}{l}\text { Strategia Rozwoju Miasta } \\
\text { Poznania } 2020+\end{array}$ & $\begin{array}{l}\text { Uchwała nr XLI/708/VII/2017 Rady } \\
\text { Miasta Poznania z dnia } 24 \text { stycznia } 2017 \text { r. }\end{array}$ \\
\hline Gdańsk & $\begin{array}{l}\text { Gdańsk } 2030 \text { Plus Strategia } \\
\text { Rozwoju Miasta }\end{array}$ & $\begin{array}{l}\text { Uchwała nr LVII/1327/14 Rady Miasta } \\
\text { Gdańska z dnia } 25 \text { września } 2014 \text { r. }\end{array}$ \\
\hline Warszawa & Strategia \#Warszawa 2030 & $\begin{array}{l}\text { Uchwała nr LXVI/1800/2018 Rady Miasta } \\
\text { Stołecznego Warszawy z dnia } 10 \text { maja } \\
2018 \text { r. }\end{array}$ \\
\hline Lublin & $\begin{array}{l}\text { Strategia Rozwoju Lublina na } \\
\text { lata 2013-2020 }\end{array}$ & $\begin{array}{l}\text { Uchwała nr 693/XXVIII/2013 Rady Miasta } \\
\text { Lublina z dnia } 28 \text { lutego } 2013 \text { r. }\end{array}$ \\
\hline \multicolumn{3}{|c|}{ Miasta - stolice subregionów } \\
\hline Sandomierz & $\begin{array}{l}\text { Strategia Rozwoju Miasta } \\
\text { Sandomierza na lata 2015-2025 }\end{array}$ & $\begin{array}{l}\text { Uchwała Nr XIX/183/2015 Rady Miasta } \\
\text { Sandomierza z dnia } 9 \text { grudnia } 2015 \text { r. }\end{array}$ \\
\hline Legnica & $\begin{array}{l}\text { Strategia Rozwoju Miasta } \\
\text { Legnicy 2015-2020 PLUS }\end{array}$ & $\begin{array}{l}\text { Uchwała Nr L/515/14 Rady Miejskiej } \\
\text { Legnicy z dnia } 27 \text { października } 2014 \text { r. }\end{array}$ \\
\hline Częstochowa & $\begin{array}{l}\text { Strategia Rozwoju Miasta } \\
\text { Częstochowa 2030+ }\end{array}$ & $\begin{array}{l}\text { Uchwała Nr 435.XXXII.2016 Rady Miasta } \\
\text { Częstochowy z dnia } 1 \text { grudnia } 2016 \text { r. }\end{array}$ \\
\hline Koszalin & Strategia Rozwoju Koszalina & $\begin{array}{l}\text { Uchwała nr XLIII/608/2018 Rady } \\
\text { Miejskiej w Koszalinie z dnia } 19 \text { kwietnia } \\
2018 \text { r. }\end{array}$ \\
\hline Grudziądz & $\begin{array}{l}\text { Strategia Rozwoju Miasta } \\
\text { Grudziądz na lata 2016-2023 }\end{array}$ & $\begin{array}{l}\text { Uchwała nr XVIII/8/16 Rady Miejskiej } \\
\text { Grudziądza z dnia } 24 \text { lutego } 2016 \text { r. }\end{array}$ \\
\hline Ciechanów & $\begin{array}{l}\text { Strategia Rozwoju Społeczno- } \\
\text {-gospodarczego Miasta } \\
\text { Ciechanów do roku } 2023 \\
\end{array}$ & $\begin{array}{l}\text { Uchwała nr 257/XXI/2016 Rady Miasta } \\
\text { Ciechanów z dnia } 30 \text { czerwca } 2016 \text { r. }\end{array}$ \\
\hline Przemyśl & $\begin{array}{l}\text { Strategia Sukcesu Miasta } \\
\text { Przemyśla na lata 2014-2024 }\end{array}$ & $\begin{array}{l}\text { Uchwała nr 27/2014 Rady Miejskiej } \\
\text { w Przemyślu z dnia } 6 \text { marca } 2014 \text { r. }\end{array}$ \\
\hline \multicolumn{3}{|c|}{ Gminy aglomeracyjne } \\
\hline Zgierz & $\begin{array}{l}\text { Strategia Zrównoważonego } \\
\text { Rozwoju dla Gminy Miasto } \\
\text { Zgierz na lata 2017-2022 } \\
\end{array}$ & $\begin{array}{l}\text { Uchwała nr XLI/527/17 Rady Miasta } \\
\text { Zgierza z dnia } 26 \text { października } 2017 \text { r. }\end{array}$ \\
\hline
\end{tabular}




\begin{tabular}{|c|c|c|}
\hline 1 & 2 & 3 \\
\hline Kąty Wrocławskie & $\begin{array}{l}\text { Strategia Rozwoju Lokalnego } \\
\text { Miasta i Gminy Katy } \\
\text { Wrocławskie do roku } 2020\end{array}$ & brak danych \\
\hline Liszki & $\begin{array}{l}\text { Strategia Rozwoju Gminy Liszki } \\
\text { na lata 2008-2013 }\end{array}$ & brak danych \\
\hline Swarzędz & $\begin{array}{l}\text { Strategia rozwoju społeczno- } \\
\text { gospodarczego Gminy Swarzędz } \\
\text { na lata 2011-2020, ,Swarzędz } \\
\text { 2020” }\end{array}$ & $\begin{array}{l}\text { Uchwała Nr XIX/167/2011 Rady Miejskiej } \\
\text { w Swarzędzu z dnia } 29 \text { listopada } 2011 \text { r. }\end{array}$ \\
\hline $\begin{array}{l}\text { Nowa } \quad \text { Wieś } \\
\text { Wielka }\end{array}$ & $\begin{array}{l}\text { Strategia rozwoju Gminy Nowa } \\
\text { Wieś Wielka do roku 2020+ }\end{array}$ & \begin{tabular}{|l} 
Uchwała nr XVI/120/16 Rady Gminy \\
Nowa Wieś Wielka z dnia 17 marca 2016 r.
\end{tabular} \\
\hline Piaseczno & $\begin{array}{l}\text { Strategia Rozwoju Miasta } \\
\text { i Gminy Piaseczno do roku } 2030\end{array}$ & $\begin{array}{l}\text { Uchwała nr 1052/XXXVI/2017 Rady } \\
\text { Miejskiej w Piasecznie z dnia } 5 \text { lipca } \\
2017 \text { r. }\end{array}$ \\
\hline Choroszcz & $\begin{array}{l}\text { Zintegrowana Strategia Rozwoju } \\
\text { Gminy Choroszcz na lata 2016- } \\
-2025\end{array}$ & $\begin{array}{l}\text { Uchwała nr XX/202/2016 Rady Miejskiej } \\
\text { w Choroszczy z dnia } 10 \text { listopada } 2016 \text { r. }\end{array}$ \\
\hline \multicolumn{3}{|c|}{ Gminy peryferyjne } \\
\hline Staszów & $\begin{array}{l}\text { Strategia Rozwoju Miasta } \\
\text { i Gminy Staszów na lata 2015- } \\
-2025\end{array}$ & $\begin{array}{l}\text { Uchwała nr X/77/15 Rady Miejskiej } \\
\text { w Staszowie z dnia } 29 \text { maja } 2015 \text { r. }\end{array}$ \\
\hline Lwówek Śląski & $\begin{array}{l}\text { Strategia Rozwoju Gminy } \\
\text { i Miasta Lwówek Śląski na lata } \\
\text { 2016-2023 }\end{array}$ & $\begin{array}{l}\text { Uchwała nr XVIII/181/16 Rady Miejskiej } \\
\text { w Lwówku Śląskim z dnia } 31 \text { marca } 2016 \text { r. }\end{array}$ \\
\hline Gorlice & $\begin{array}{l}\text { Strategia Rozwoju Gminy Gorlice } \\
\text { na lata 2013-2020+ }\end{array}$ & $\begin{array}{l}\text { Uchwała Nr XX/200/13 Rady Gminy } \\
\text { Gorlice z dnia } 30 \text { stycznia } 2013 \text { r. }\end{array}$ \\
\hline Okonek & $\begin{array}{l}\text { Strategia rozwoju Gminy Okonek } \\
\text { na lata 2012-2020 }\end{array}$ & $\begin{array}{l}\text { Uchwała nr XXVII/133/2012 Rady } \\
\text { Miejskiej z dnia } 23 \text { kwietnia } 2012 \text { r. }\end{array}$ \\
\hline Giżycko & $\begin{array}{l}\text { Strategia Rozwoju Miasta } \\
\text { Giżycka na lata 2015-2025 }\end{array}$ & $\begin{array}{l}\text { Uchwała nr XXVII/106/2016 Rady } \\
\text { Miejskiej w Giżycku z dnia } 28 \text { września } \\
\text { 2016 r }\end{array}$ \\
\hline Przysucha & $\begin{array}{l}\text { Strategia Rozwoju Lokalnego } \\
\text { Gminy i Miasta Przysucha do } \\
2020\end{array}$ & $\begin{array}{l}\text { Uchwała nr XIII/101/2015 Rady Gminy } \\
\text { i Miasta Przysucha z dnia } 17 \text { grudnia } 2015 \text { r. }\end{array}$ \\
\hline Tyszowce & $\begin{array}{l}\text { Strategia Rozwoju Gminy } \\
\text { Tyszowce na lata 2015-2020 }\end{array}$ & $\begin{array}{l}\text { Uchwała Nr XVII/117/2016 Rady } \\
\text { Miejskiej w Tyszowcach z dnia } 10 \text { czerwca } \\
2016 \text { r. }\end{array}$ \\
\hline
\end{tabular}

Źródło: opracowanie własne na podstawie biuletynów informacji publicznej gmin.

Indywidualne wywiady pogłębione zostały przeprowadzone telefonicznie w oparciu o scenariusz, którego elementem były pytania kwestionariuszowe zamknięte zawierające kafeterię odpowiedzi oraz pytania otwarte. Pytania kwestionariuszowe i uzyskane wyniki badania zostały zaprezentowane w podpunkcie 4.3 artykułu. 


\section{Wyniki badań dotyczących podejść do strategii w gminach w Polsce}

\subsection{Wyniki oceny opisowej strategii gmin w Polsce}

Oceny opisowej strategii gmin dokonano zgodnie z założeniami badawczymi. Stanowiła ona podstawę badań w kolejnych etapach. Ze względu jednak na jej dużą objętość poniżej przedstawiono tylko uogólnione wyniki analizy gmin w Polsce.

$\mathrm{W}$ odniesieniu do pytania pierwszego - o to, w jakim stopniu analiza strategiczna koncentruje się na czynnikach wewnętrznych, a w jakim na zewnętrznych, wyniki badania wskazują, że analiza strategiczna gmin objętych badaniem koncentruje się przede wszystkim na czynnikach wewnętrznych. Otoczenie jednostek samorządu terytorialnego, czynniki egzogeniczne, trendy i zjawiska makroekonomiczne, które mogą mieć istotny wpływ na rozwój gmin, są przedmiotem diagnoz w ograniczonym zakresie, a w niektórych przypadkach stanowią szczątkowy element analizy strategicznej. Odniesienia do czynników zewnętrznych można odnaleźć częściej w strategiach dużych miast. Stolice regionów pozycjonują się na tle konkurentów podobnej wielkości w Polsce, a także na tle metropolii zagranicznych i uwzględniają w analizie czynniki polityczne, ekonomiczne, społeczne, technologiczne. Gminy aglomeracyjne i gminy peryferyjne w równym stopniu są nastawione głównie na diagnozowanie czynników wewnętrznych i marginalizowanie znaczenia (przynajmniej w tekście strategii) czynników zewnętrznych. Wniosek taki jest szczególnie zaskakujący w odniesieniu do gmin aglomeracyjnych, których rozwój w dużo większym stopniu niż w przypadku gmin oddalonych od aglomeracji miejskich jest uwarunkowany przez otoczenie.

Z kolei w odpowiedzi na pytanie drugie o wskazanie zasobów, na jakich koncentruje się analiza strategiczna, należy stwierdzić koncentrację na zasobach materialnych. Diagnoza dotycząca infrastruktury sieciowej i liniowej, bazy materialnej instytucji administracji samorządowej jest zazwyczaj dużo obszerniejsza i bardziej szczegółowa niż diagnoza zasobów niematerialnych. Zasoby materialne są oceniane w wąskim zakresie m.in. przez pryzmat skąpych danych o kompetencjach zasobów ludzkich (głównie uczniów szkół) czy przez pryzmat ogólnikowo opisanej oferty kulturalnej i sportowej. Marka gminy czy niematerialny potencjał instytucji gminnych rzadko podlegają głębszej analizie. Przytaczane wyniki badań socjologicznych realizowanych na potrzeby opracowania strategii również częściej odnoszą się do oceny zasobów materialnych przez mieszkańców niż do oceny potencjału niematerialnego gminy. Proporcje między diagnozą zasobów materialnych i niematerialnych rozkładają się różnie w zależności od charakteru badanej jednostki samorządu terytorialnego. W analizie strategicznej miast - stolic regionów proporcje te są stosunkowo zrównoważone, a nawet niektóre duże miasta położyły większy nacisk na za- 
soby niematerialne niż materialne, skupiając się na zasobach kompetencyjnych, marce miasta, wizerunku, ofercie kulturalnej. W pozostałych badanych typach jednostek uwaga autorów diagnoz koncentruje się na zasobach materialnych, co można zaobserwować szczególnie w przypadku gmin aglomeracyjnych, które analizują głównie ilościowe dane o infrastrukturze i bazie materialnej należącej do mienia komunalnego gmin.

Miasta duże i średnie w analizach strategicznych starają się porównać z innymi jednostkami terytorialnymi o podobnej wielkości i funkcjach, co mogłoby sugerować podejście pozycyjne do strategii, jednak zazwyczaj są to porównania stosunkowo płytkie pod względem wnioskowania i nie wnoszą wiele do oceny konkurencyjności wobec otoczenia.

Analiza zasobów innowacyjnych i sieciowych została podjęta w niewielkim zakresie w strategiach rozwoju miast - stolic regionów. W pozostałych typach badanych jednostek praktycznie nie dokonano oceny tych zasobów.

Pytanie trzecie dotyczyło czynników rozwojowych, na których koncentruje się strategia budowana w oparciu o analizę SWOT. Zawarta w badanych dokumentach strategicznych gmin analiza SWOT zazwyczaj ogranicza się do tabeli, w której wyszczególniono czynniki rozwojowe w postaci krótkich haseł, dzięki czemu możliwe jest zliczenie liczby zdefiniowanych mocnych i słabych stron, a następnie zestawienie z liczbą szans i zagrożeń. $Z$ jednym wyjątkiem w strategiach nad czynnikami zewnętrznymi dominują czynniki wewnętrzne. Korygując błędy, które często popełniano przy identyfikacji szans i zagrożeń, utożsamiając je ze scenariuszami rozwoju lub postulatami, można podać procentowy udział dwóch grup czynników w analizie SWOT w strategiach poddanych badaniu. Grupa czynników wewnętrznych (mocne i słabe strony) stanowi blisko $70 \%$ wszystkich czynników rozwojowych. W całej grupie objętej badaniem średnio można zliczyć niecałe 30\% szans i zagrożeń. Duża koncentracja gmin na czynnikach wewnętrznych jest z pewnością związana z tym, że, po pierwsze, są to czynniki, na które samorządy mają wpływ, po drugie zaś czynniki te stosunkowo łatwiej zidentyfikować w procesie analizy strategicznej. Wnioski w tej części są spójne z wnioskami odnoszącymi się do badania, na jakich zasobach (wewnętrznych czy zewnętrznych) gminy koncentrują się w analizie strategicznej, tj. w opisowej części diagnozy, która poprzedza analizę SWOT. Wnioski zawarte w SWOT często nie mają swoich odpowiedników w diagnozie stanu, co świadczy o tym, że opracowanie diagnozy i wylistowanie mocnych, słabych stron, szans i zagrożeń to dwa odrębne procesy.

Pytanie czwarte odnosiło się do działań, na jakich koncentruje się strategia w części postulatywnej, i do sposobu budowania przewagi konkurencyjnej. Postulaty strategiczne (cele i zadania) gmin objętych badaniem koncentrują się głównie na zasobach własnych. Dominującym podejściem jest zaspokojenie potrzeb obecnych mieszkańców i przedsiębiorców poprzez ilościowy rozwój i modernizację zasobów materialnych. Równolegle, choć z mniejszym natężeniem, w analizowanych strate- 
giach grupami docelowymi planowanych działań są przyszli mieszkańcy, przedsiębiorcy i turyści. Postulaty odnoszące się do rozwoju zasobów niematerialnych, w tym kompetencji mieszkańców i kompetencji organizacyjno-instytucjonalnych administracji samorządowej stanowiących wartość dla mieszkańców, rozwijania pozamaterialnych zasobów dziedzictwa kulturowego czy też budowania marki są w mniejszości, choć nie ustępują znacznie postulatom skoncentrowanym na zasobach materialnych. W strategiach miast wojewódzkich, w odróżnieniu od gmin z pozostałych grup, można nawet dostrzec przewagę postulatów dotyczących zasobów niematerialnych nad postulatami odnoszącymi się do zasobów materialnych.

Analizując treść części programowej strategii gmin polskich, trudno dostrzec skupienie uwagi na potencjalnych konkurentach. Przyjmując z pozycji badacza perspektywę postrzegania gminy jako produktu lub zbioru produktów (grunty inwestycyjne, zasoby mieszkaniowe, zasoby przyrodnicze, usługi edukacyjne, usługi turystyczne itd.), rzadko w postulatach strategicznych można zaobserwować deklaracje zwiększenia udziału w rynku, poszukiwania uprzywilejowanej pozycji i wyróżniania się jako strategii budowania przewagi konkurencyjnej. Częściej niż inne grupy samorządów postulują takie podejście duże miasta - stolice regionów, które pozycjonują się względem innych dużych miast polskich i zagranicznych.

Planując cele i zadania, niewiele uwagi gminy poświęcają tworzeniu i rozwijaniu innowacji. Postulaty związane z innowacyjnością odnoszą się częściej do sektorów innych niż samorządowy lub są ledwie zasygnalizowane w celach, ale nieobecne w zadaniach. Postulaty badanych gmin jeszcze rzadziej koncentrują się na określeniu swojej pozycji w sieci i wykorzystaniu sieci w rozwoju. Dotyczy to również gmin aglomeracyjnych. Cześsciej niż inne grupy samorządów do innowacji i oparcia rozwoju na korzyściach wynikających ze współpracy w obrębie sektora samorządowego i poza nim odwołują się miasta wojewódzkie.

\subsection{Wyniki oceny punktowej strategii gmin w Polsce}

Ocenę punktową strategii gmin dokonaną zgodnie z założeniami badawczymi przedstawiono w podziale na pytania stanowiące główne kryteria oceny podejścia do strategii w gminach.

W tabeli 7 przedstawiono wyniki oceny punktowej stopnia nasilenia cechy związanej z koncentracją analizy strategicznej na zasobach wewnętrznych lub zewnętrznych.

W tabeli 8 przedstawiono wyniki analizy intensywności koncentracji gminy na różnych kategoriach zasobów.

W tabeli 9 wskazano, na jakich czynnikach rozwojowych koncentruje się z kolei strategia budowana w oparciu o analizę SWOT (nasilenie cechy).

$\mathrm{W}$ tabeli 10 analizowano stopień nasilenia cechy związanej z działaniami, na jakich koncentruje się strategia w części postulatywnej w badanych gminach. 
Tabela 7. Ocena punktowa według kryterium: w jakim stopniu analiza strategiczna koncentruje się na czynnikach wewnętrznych, a w jakim na czynnikach zewnętrznych w badanych gminach?

\begin{tabular}{|c|c|c|}
\hline Gmina & $\begin{array}{c}\text { Analiza strategiczna } \\
\text { koncentruje się } \\
\text { na czynnikach } \\
\text { wewnętrznych }\end{array}$ & $\begin{array}{c}\text { Analiza strategiczna } \\
\text { koncentruje się } \\
\text { na czynnikach } \\
\text { zewnętrznych }\end{array}$ \\
\hline \multicolumn{3}{|c|}{ Miasta - stolice regionów } \\
\hline Łódź & 5 & 2 \\
\hline Wrocław & 5 & 4 \\
\hline Kraków & 5 & 2 \\
\hline Poznań & 5 & 3 \\
\hline Gdańsk & 5 & 3 \\
\hline Warszawa & 5 & 4 \\
\hline Lublin & 5 & 1 \\
\hline \multicolumn{3}{|c|}{ Miasta - stolice subregionów } \\
\hline Sandomierz & 5 & 1 \\
\hline Legnica & 5 & 2 \\
\hline Częstochowa & 5 & 3 \\
\hline Koszalin & 5 & 0 \\
\hline Grudziądz & 5 & 2 \\
\hline Ciechanów & 5 & 0 \\
\hline Przemyśl & 5 & 0 \\
\hline \multicolumn{3}{|c|}{ Gminy aglomeracyjne } \\
\hline Zgierz & 5 & 0 \\
\hline Kąty Wrocławskie & 5 & 1 \\
\hline Liszki & 5 & 1 \\
\hline Swarzędz & 5 & 0 \\
\hline Nowa Wieś Wielka & 5 & 1 \\
\hline Piaseczno & 5 & 1 \\
\hline Choroszcz & 5 & 1 \\
\hline \multicolumn{3}{|c|}{ Gminy peryferyjne } \\
\hline Staszów & 5 & 1 \\
\hline Lwówek Śląski & 5 & 1 \\
\hline Gorlice & 5 & 1 \\
\hline Okonek & 5 & 1 \\
\hline Giżycko & 5 & 2 \\
\hline Przysucha & 5 & 0 \\
\hline Tyszowce & 5 & 2 \\
\hline
\end{tabular}

Objaśnienia: ocena w skali 0-5 na podstawie obserwacji własnych, gdzie 1 oznacza, że w strategii gminy dana cecha uwidoczniła się w niewielkim stopniu, 5 oznacza, że dana cecha uwidoczniła się w bardzo dużym stopniu. Ocena 0 oznacza, że dana cecha w ogóle nie została zaobserwowana. W ocenie wzięto pod uwagę proporcje treści poddanych badaniu dokumentów odpowiadających cechom określonych wyróżników.

Źródło: opracowanie własne na podstawie przeprowadzonych badań empirycznych. 
Tabela 8. Ocena punktowa według kryterium: na jakich zasobach koncentruje się analiza strategiczna w badanych gminach?

\begin{tabular}{|c|c|c|c|c|c|}
\hline Gmina & 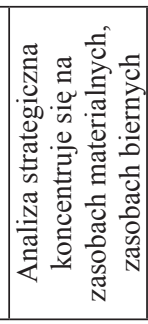 & 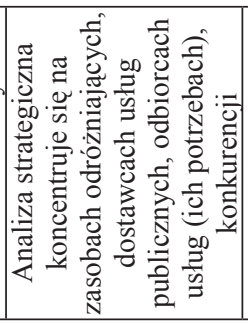 & 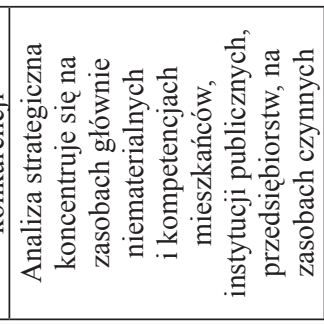 & 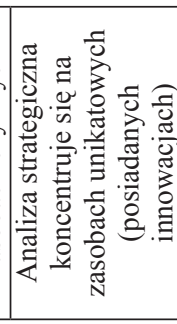 & 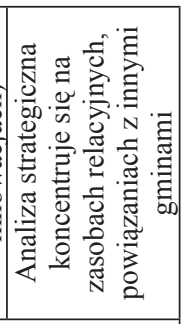 \\
\hline \multicolumn{6}{|c|}{ Miasta - stolice regionów } \\
\hline Łódź & 4 & 3 & 4 & 1 & 2 \\
\hline \begin{tabular}{|l|} 
Wrocław \\
\end{tabular} & 4 & 2 & 2 & 3 & 2 \\
\hline Kraków & 3 & 3 & 4 & 4 & 1 \\
\hline Poznań & 5 & 3 & 3 & 3 & 2 \\
\hline Gdańsk & 4 & 3 & 4 & 1 & 2 \\
\hline Warszawa & 3 & 4 & 4 & 1 & 2 \\
\hline Lublin & 5 & 2 & 2 & 1 & 1 \\
\hline \multicolumn{6}{|c|}{ Miasta - stolice subregionów } \\
\hline Sandomierz & 5 & 2 & 1 & 0 & 1 \\
\hline Legnica & 5 & 3 & 3 & 1 & 0 \\
\hline Częstochowa & 5 & 3 & 3 & 0 & 1 \\
\hline Koszalin & 5 & 1 & 1 & 1 & 1 \\
\hline Grudziądz & 5 & 2 & 2 & 0 & 1 \\
\hline Ciechanów & 5 & 1 & 1 & 0 & 1 \\
\hline \begin{tabular}{|l|} 
Przemyśl \\
\end{tabular} & 5 & 2 & 2 & 0 & 1 \\
\hline \multicolumn{6}{|c|}{ Gminy aglomeracyjne } \\
\hline Zgierz & 5 & 1 & 2 & 0 & 0 \\
\hline Kąty Wrocławskie & 5 & 1 & 1 & 0 & 0 \\
\hline Liszki & 5 & 1 & 2 & 0 & 0 \\
\hline Swarzędz & 5 & 0 & 2 & 0 & 0 \\
\hline Nowa Wieś Wielka & 5 & 1 & 2 & 0 & 0 \\
\hline Piaseczno & 4 & 1 & 3 & 0 & 0 \\
\hline Choroszcz & 5 & 1 & 2 & 0 & 0 \\
\hline \multicolumn{6}{|c|}{ Gminy peryferyjne } \\
\hline Staszów & 2 & 1 & 3 & 0 & 0 \\
\hline Lwówek Śląski & 5 & 1 & 1 & 0 & 0 \\
\hline Gorlice & 5 & 1 & 3 & 0 & 0 \\
\hline Okonek & 5 & 1 & 2 & 0 & 1 \\
\hline \begin{tabular}{|l|} 
Giżycko \\
\end{tabular} & 5 & 3 & 3 & 1 & 1 \\
\hline Przysucha & 5 & 0 & 1 & 0 & 0 \\
\hline Tyszowce & 5 & 1 & 1 & 0 & 1 \\
\hline
\end{tabular}

Objaśnienia: ocena w skali 0-5 na podstawie obserwacji własnych, gdzie 1 oznacza, że w strategii gminy dana cecha uwidoczniła się w niewielkim stopniu, 5 oznacza, że dana cecha uwidoczniła się w bardzo dużym stopniu. Ocena 0 oznacza, że dana cecha w ogóle nie została zaobserwowana. W ocenie wzięto pod uwagę proporcje treści poddanych badaniu dokumentów odpowiadających cechom określonych wyróżników.

Źródło: opracowanie własne na podstawie przeprowadzonych badań empirycznych. 
Tabela 9. Ocena punktowa według kryterium: na jakich czynnikach rozwojowych koncentrują się strategie budowane w oparciu o analizę SWOT w badanych gminach?

\begin{tabular}{|c|c|c|}
\hline Gmina & $\begin{array}{c}\text { W analizie SWOT budowane } \\
\text { strategie koncentrują się } \\
\text { na SW }\end{array}$ & $\begin{array}{c}\text { W analizie SWOT budowane } \\
\text { strategie koncentrują się } \\
\text { na OT }\end{array}$ \\
\hline \multicolumn{3}{|c|}{ Miasta - stolice regionów } \\
\hline Łódź & 3 & 2 \\
\hline Wrocław & 1 & 4 \\
\hline Kraków & 3 & 2 \\
\hline Poznań & 3 & 2 \\
\hline Gdańsk & 3 & 2 \\
\hline Warszawa & 3 & 2 \\
\hline Lublin & 4 & 1 \\
\hline \multicolumn{3}{|c|}{ Miasta - stolice subregionów } \\
\hline Sandomierz & 4 & 1 \\
\hline Legnica & 3 & 2 \\
\hline Częstochowa & 4 & 1 \\
\hline Koszalin & 3 & 2 \\
\hline Grudziądz & 3 & 2 \\
\hline Ciechanów & 4 & 1 \\
\hline Przemyśl & 3 & 2 \\
\hline \multicolumn{3}{|c|}{ Gminy aglomeracyjne } \\
\hline Zgierz & 4 & 1 \\
\hline Kąty Wrocławskie & 4 & 1 \\
\hline Liszki & 3 & 2 \\
\hline Swarzędz & 5 & 0 \\
\hline Nowa Wieś Wielka & 3 & 2 \\
\hline Piaseczno & 4 & 1 \\
\hline Choroszcz & 4 & 1 \\
\hline \multicolumn{3}{|c|}{ Gminy peryferyjne } \\
\hline Staszów & 4 & 1 \\
\hline Lwówek Śląski & 4 & 1 \\
\hline Gorlice & 3 & 2 \\
\hline Okonek & 4 & 1 \\
\hline Giżycko & 4 & 1 \\
\hline Przysucha & 4 & 1 \\
\hline Tyszowce & 4 & 1 \\
\hline
\end{tabular}

Objaśnienia: ocena w skali 0-5 na podstawie obserwacji własnych, gdzie 1 oznacza, że w strategii gminy dana cecha uwidoczniła się w niewielkim stopniu, 5 oznacza, że dana cecha uwidoczniła się w bardzo dużym stopniu. Ocena 0 oznacza, że dana cecha w ogóle nie została zaobserwowana. W ocenie wzięto pod uwagę proporcje treści poddanych badaniu dokumentów odpowiadających cechom określonych wyróżników.

Źródło: opracowanie własne na podstawie przeprowadzonych badań empirycznych. 
Tabela 10. Ocena punktowa według kryterium: na jakich działaniach koncentruje się strategia w części postulatywnej w badanych gminach? W jaki sposób buduje przewagę konkurencyjną w badanych gminach?

\begin{tabular}{|c|c|c|c|c|c|}
\hline Gmina & 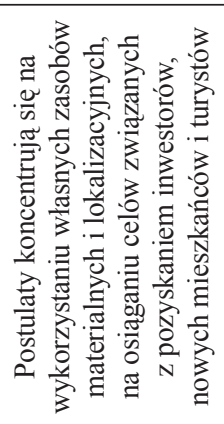 & 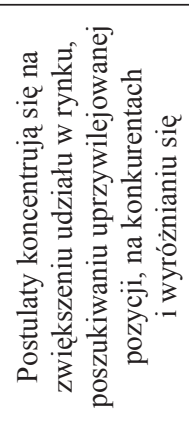 & 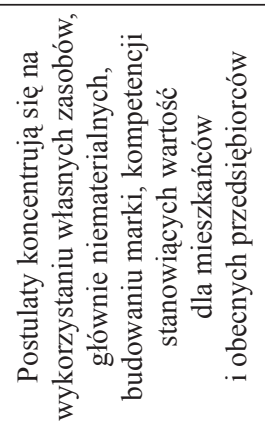 & 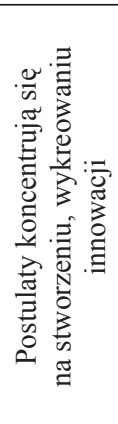 & 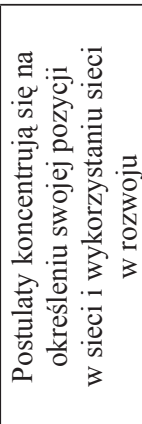 \\
\hline \multicolumn{6}{|c|}{ Miasta - stolice regionów } \\
\hline Łódź & 3 & 2 & 4 & 3 & 3 \\
\hline Wrocław & 3 & 3 & 5 & 3 & 3 \\
\hline Kraków & 3 & 3 & 5 & 4 & 3 \\
\hline Poznań & 2 & 2 & 5 & 3 & 3 \\
\hline Gdańsk & 2 & 2 & 4 & 1 & 2 \\
\hline Warszawa & 2 & 1 & 4 & 2 & 1 \\
\hline Lublin & 4 & 2 & 4 & 2 & 3 \\
\hline \multicolumn{6}{|c|}{ Miasta - stolice subregionów } \\
\hline Sandomierz & 4 & 1 & 4 & 1 & 3 \\
\hline Legnica & 4 & 1 & 2 & 2 & 1 \\
\hline Częstochowa & 4 & 1 & 2 & 1 & 0 \\
\hline Koszalin & 4 & 1 & 2 & 2 & 0 \\
\hline Grudziądz & 4 & 1 & 4 & 2 & 1 \\
\hline Ciechanów & 4 & 1 & 2 & 1 & 1 \\
\hline Przemyśl & 4 & 1 & 4 & 0 & 1 \\
\hline \multicolumn{6}{|c|}{ Gminy aglomeracyjne } \\
\hline Zgierz & 4 & 1 & 4 & 0 & 0 \\
\hline Katy Wrocławskie & 4 & 1 & 4 & 1 & 3 \\
\hline Liszki & 4 & 1 & 3 & 0 & 1 \\
\hline Swarzędz & 5 & 2 & 4 & 1 & 2 \\
\hline Nowa Wieś Wielka & 4 & 0 & 4 & 0 & 0 \\
\hline Piaseczno & 5 & 1 & 3 & 2 & 0 \\
\hline Choroszcz & 5 & 1 & 2 & 0 & 0 \\
\hline \multicolumn{6}{|c|}{ Gminy peryferyjne } \\
\hline Staszów & 4 & 1 & 4 & 1 & 0 \\
\hline Lwówek Śląski & 5 & 1 & 2 & 0 & 1 \\
\hline Gorlice & 4 & 1 & 4 & 2 & 1 \\
\hline Okonek & 4 & 1 & 4 & 0 & 1 \\
\hline Giżycko & 4 & 3 & 4 & 3 & 1 \\
\hline Przysucha & 4 & 0 & 2 & 0 & 0 \\
\hline Tyszowce & 5 & 0 & 2 & 1 & 0 \\
\hline
\end{tabular}

Objaśnienia: ocena w skali 0-5 na podstawie obserwacji własnych, gdzie 1 oznacza, że w strategii gminy dana cecha uwidoczniła się w niewielkim stopniu, 5 oznacza, że dana cecha uwidoczniła się w bardzo dużym stopniu. Ocena 0 oznacza, że dana cecha w ogóle nie została zaobserwowana. W ocenie wzięto pod uwagę proporcje treści poddanych badaniu dokumentów odpowiadających cechom określonych wyróżników.

Źródło: opracowanie własne na podstawie przeprowadzonych badań empirycznych. 


\subsection{Interpretacja wyników badań strategii gmin w Polsce}

W tabeli 11 zaprezentowano wszystkie wybrane do analizy strategii gmin wyróżniki podejść: planistycznego, pozycyjnego, zasobowego, innowacyjnego i sieciowego. Wyróżników każdego podejścia jest więcej, jednak nie wszystkie można zastosować do analizy strategii samorządów, o czym pisano już w części teoretycznej.

Tabela 11. Wyróżniki podejścia planistycznego, pozycyjnego, zasobowego, innowacyjnego i sieciowego wybrane do analizy strategii gmin

\begin{tabular}{|c|c|c|c|c|c|}
\hline & \multicolumn{5}{|c|}{ Podejście } \\
\hline & planistyczne & pozycyjne & zasobowe & innowacyjne & sieciowe \\
\hline \multirow{4}{*}{ 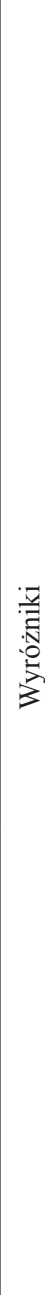 } & $\begin{array}{l}\text { analiza strategiczna } \\
\text { koncentruje się } \\
\text { na czynnikach } \\
\text { wewnętrznych }\end{array}$ & $\begin{array}{l}\text { analiza } \\
\text { strategiczna } \\
\text { koncentruje się } \\
\text { na czynnikach } \\
\text { zewnętrznych }\end{array}$ & $\begin{array}{l}\text { analiza strategiczna } \\
\text { koncentruje się } \\
\text { na czynnikach } \\
\text { wewnętrznych }\end{array}$ & $\begin{array}{l}\text { analiza } \\
\text { strategiczna } \\
\text { koncentruje się } \\
\text { na czynnikach } \\
\text { zewnętrznych }\end{array}$ & $\begin{array}{l}\text { analiza } \\
\text { strategiczna } \\
\text { koncentruje się } \\
\text { na czynnikach } \\
\text { zewnętrznych }\end{array}$ \\
\hline & $\begin{array}{l}\text { analiza strategiczna } \\
\text { koncentruje się } \\
\text { na zasobach } \\
\text { materialnych, } \\
\text { zasobach biernych }\end{array}$ & $\begin{array}{l}\text { analiza } \\
\text { strategiczna } \\
\text { koncentruje się } \\
\text { na zasobach } \\
\text { odróżniających, } \\
\text { dostawcach usług } \\
\text { publicznych, } \\
\text { odbiorcach usług } \\
\text { (ich potrzebach), } \\
\text { konkurencji }\end{array}$ & $\begin{array}{l}\text { analiza strategiczna } \\
\text { koncentruje się na } \\
\text { zasobach głównie } \\
\text { niematerialnych } \\
\text { i kompetencjach } \\
\text { mieszkańców, } \\
\text { instytucji } \\
\text { publicznych, } \\
\text { przedsiębiorstw, na } \\
\text { zasobach czynnych }\end{array}$ & $\begin{array}{l}\text { analiza } \\
\text { strategiczna } \\
\text { koncentruje się } \\
\text { na zasobach } \\
\text { unikatowych } \\
\text { (posiadanych } \\
\text { innowacjach) }\end{array}$ & $\begin{array}{l}\text { analiza } \\
\text { strategiczna } \\
\text { koncentruje się } \\
\text { na zasobach } \\
\text { relacyjnych, } \\
\text { powiązaniach } \\
\text { z innymi } \\
\text { gminami }\end{array}$ \\
\hline & $\begin{array}{l}\text { w analizie SWOT } \\
\text { budowane strategie } \\
\text { koncentrują się na } \\
\text { SW }\end{array}$ & $\begin{array}{l}\text { w analizie SWOT } \\
\text { budowane } \\
\text { strategie } \\
\text { koncentrują się } \\
\text { na OT }\end{array}$ & $\begin{array}{l}\text { w analizie SWOT } \\
\text { budowane strategie } \\
\text { koncentrują się na } \\
\text { SW }\end{array}$ & $\begin{array}{l}\text { w analizie } \\
\text { SWOT } \\
\text { budowane } \\
\text { strategie } \\
\text { koncentrują się } \\
\text { na OT }\end{array}$ & $\begin{array}{l}\text { w analizie } \\
\text { SWOT } \\
\text { budowane } \\
\text { strategie } \\
\text { koncentrują się } \\
\text { na OT }\end{array}$ \\
\hline & $\begin{array}{l}\text { postulaty } \\
\text { koncentrują się } \\
\text { na wykorzystaniu } \\
\text { własnych zasobów } \\
\text { materialnych } \\
\text { i lokalizacyjnych, } \\
\text { na osiaganiu } \\
\text { celów związanych } \\
\text { z pozyskaniem } \\
\text { inwestorów, nowych } \\
\text { mieszkańców } \\
\text { i turystów }\end{array}$ & $\begin{array}{l}\text { postulaty } \\
\text { koncentrują się } \\
\text { na zwiększeniu } \\
\text { udziału w rynku, } \\
\text { poszukiwaniu } \\
\text { uprzywilejowanej } \\
\text { pozycji, na } \\
\text { konkurentach } \\
\text { i wyróżnianiu się }\end{array}$ & $\begin{array}{l}\text { postulaty koncentrują } \\
\text { się na wykorzystaniu } \\
\text { własnych } \\
\text { zasobów, głównie } \\
\text { niematerialnych, } \\
\text { budowaniu marki, } \\
\text { kompetencji } \\
\text { stanowiących wartość } \\
\text { dla mieszkańców } \\
\text { i obecnych } \\
\text { przedsiębiorców }\end{array}$ & $\begin{array}{l}\text { postulaty } \\
\text { koncentrują się } \\
\text { na stworzeniu, } \\
\text { wykreowaniu } \\
\text { innowacji }\end{array}$ & $\begin{array}{l}\text { postulaty } \\
\text { koncentrują się } \\
\text { na określeniu } \\
\text { swojej pozycji } \\
\text { w sieci i } \\
\text { wykorzystaniu } \\
\text { sieci w rozwoju }\end{array}$ \\
\hline
\end{tabular}

Źródło: opracowanie własne na podstawie przeprowadzonych badań empirycznych. 
Interpretacja wyników przeprowadzonych badań wymaga określenia wskaźników syntetyzujących wyróżniki każdego podejścia z osobna, aby następnie móc ustalić, które podejście dominuje. Przyjęta pięciostopniowa skala oceny występowania cech wyróżniających podejście do strategii ułatwia procedurę analizy i interpretacji wyników. Procedura przedstawia się następująco:

1) sporządzenie dwuwymiarowej tablicy, w której gminom przyporządkowano oceny punktowe;

2) przypisanie wag poszczególnym wyróżnikom (w tab. 12 zaprezentowano ten etap procedury);

3) przemnożenie oceny przez wagi w poszczególnych wyróżnikach;

4) dodanie ocen według wszystkich wyróżników przypisanych do każdego podejścia (zob. tab. 13);

5) obliczenie średniej arytmetycznej dla każdej kategorii gmin (zob. tab. 13);

6) obliczenie średniej arytmetycznej dla wszystkich gmin (zob. tab. 13).

Tabela 12. Wagi przypisane wyróżnikom podejścia do strategii ${ }^{6}$

\begin{tabular}{|l|l|r|}
\hline \multicolumn{1}{|c|}{ Kryteria oceny } & \multicolumn{1}{|c|}{ Wyróżniki } & WAGA \\
\hline \multicolumn{1}{|c|}{1} & \multicolumn{1}{|c|}{2} & \multicolumn{1}{|c|}{3} \\
\hline $\begin{array}{l}\text { W jakim stopniu analiza } \\
\text { strategiczna koncentruje się } \\
\text { na czynnikach wewnętrznych, } \\
\text { a w jakim na czynnikach } \\
\text { zewnętrznych? }\end{array}$ & $\begin{array}{l}\text { analiza strategiczna koncentruje się na czynnikach } \\
\text { wewnętrznych }\end{array}$ & $\begin{array}{l}\text { analiza strategiczna koncentruje się na czynnikach } \\
\text { zewnętrznych }\end{array}$ \\
\hline $\begin{array}{l}\text { Na jakich zasobach koncentruje } \\
\text { się analiza strategiczna? }\end{array}$ & $\begin{array}{l}\text { analiza strategiczna koncentruje się na zasobach } \\
\text { materialnych, zasobach biernych }\end{array}$ & 0,50 \\
\cline { 2 - 3 } & $\begin{array}{l}\text { analiza strategiczna koncentruje się na zasobach } \\
\text { odróżniających, dostawcach, odbiorcach, } \\
\text { konkurencji, nowych oferentach, substytutach }\end{array}$ & 1,00 \\
\hline
\end{tabular}

${ }^{6}$ Wagi zostały przypisane według następujących zasad. Łącznie wagę równą 2 przypisano wyróżnikom, które były badane na poziomie analizy strategicznej i analizy SWOT. Waga równa 2 została przypisana do wyróżników, które były badane na poziomie części postulatywnej strategii. W ten sposób obie części, tj. diagnostyczna i postulatywna, mają taką samą wagę. W obrębie analizy strategicznej wagę równą 0,5 przypisano do wyróżników dotyczących natury czynników rozwojowych dominujących $\mathrm{w}$ analizie strategicznej i podobnie w analizie SWOT. Analiza SWOT jest zgodnie z teorią podsumowaniem diagnozy, dlatego badanie dotyczące tego, które czynniki rozwojowe dominują, może wydawać się dublowaniem oceny według podobnego kryterium. Praktyka, niestety niewłaściwa, opracowania diagnozy i analizy SWOT stosowana przez gminy jest taka, że diagnoza i analiza SWOT sa tylko częściowo zgodne. Aby jednak rozwiać wątpliwości metodologiczne, uznano, że należy przypisać wszystkim wyróżnikom odnoszącym się do natury czynników rozwojowych (wewnętrzne vs zewnętrzne) wagę 0,5 . W konsekwencji, podając przykład, łącznie w obrębie podejścia planistycznego i zasobowego wyróżniki „analiza strategiczna koncentruje się na czynnikach wewnętrznych” i wyróżnik „W analizie SWOT budowane strategie koncentrują się na SW" mają wagę równą 1. Taką również wagę przypisano do wyróżników przyporządkowanych kryterium „Na jakich zasobach koncentruje się analiza strategiczna?". 


\begin{tabular}{|c|c|c|}
\hline \multirow[t]{4}{*}{1} & 2 & 3 \\
\hline & $\begin{array}{l}\text { analiza strategiczna koncentruje się na zasobach } \\
\text { i kompetencjach głównie niematerialnych } \\
\text { mieszkańców, instytucji publicznych, } \\
\text { przedsiębiorstw, na zasobach czynnych }\end{array}$ & 1,00 \\
\hline & $\begin{array}{l}\text { analiza strategiczna koncentruje się na zasobach } \\
\text { unikatowych (posiadanych innowacjach) }\end{array}$ & 1,00 \\
\hline & $\begin{array}{l}\text { analiza strategiczna koncentruje się na zasobach } \\
\text { relacyjnych, powiązaniach z innymi gminami }\end{array}$ & 1,00 \\
\hline \multirow{2}{*}{$\begin{array}{l}\text { Na jakich czynnikach } \\
\text { rozwojowych koncentrują się } \\
\text { strategie budowane w oparciu } \\
\text { o analizę SWOT? }\end{array}$} & $\begin{array}{l}\text { w analizie SWOT budowane strategie koncentrują } \\
\text { się na SW }\end{array}$ & 0,50 \\
\hline & $\begin{array}{l}\text { w analizie SWOT budowane strategie koncentrują } \\
\text { się na OT }\end{array}$ & 0,50 \\
\hline \multirow[t]{5}{*}{$\begin{array}{l}\text { Na jakich działaniach } \\
\text { koncentruje się strategia w części } \\
\text { postulatywnej? W jaki sposób } \\
\text { buduje przewagę konkurencyjną? }\end{array}$} & $\begin{array}{l}\text { postulaty koncentrują się na wykorzystaniu } \\
\text { własnych zasobów materialnych } \\
\text { i lokalizacyjnych, na osiaganiu celów związanych } \\
\text { z pozyskaniem inwestorów, nowych mieszkańców } \\
\text { i turystów }\end{array}$ & 2,00 \\
\hline & $\begin{array}{l}\text { postulaty koncentrują się na zwiększeniu udziału } \\
\text { w rynku, poszukiwaniu uprzywilejowanej pozycji, } \\
\text { na konkurentach i wyróżnianiu się }\end{array}$ & 2,00 \\
\hline & $\begin{array}{l}\text { postulaty koncentrują się na wykorzystaniu } \\
\text { własnych zasobów, głównie niematerialnych, } \\
\text { budowaniu marki, kompetencji stanowiących } \\
\text { wartość dla mieszkańców i obecnych } \\
\text { przedsiębiorców }\end{array}$ & 2,00 \\
\hline & $\begin{array}{l}\text { postulaty koncentrują się na stworzeniu, } \\
\text { wykreowaniu innowacji }\end{array}$ & 2,00 \\
\hline & $\begin{array}{l}\text { postulaty koncentrują się na określeniu swojej } \\
\text { pozycji w sieci i wykorzystaniu sieci w rozwoju }\end{array}$ & 2,00 \\
\hline
\end{tabular}

Źródło: opracowanie własne na podstawie przeprowadzonych badań empirycznych.

Na rysunku 1 zaprezentowano średnią arytmetyczną oceny przemnożonej przez wagę wszystkich wyróżników dla badanych gmin łącznie. Informacje widoczne na wykresie są podsumowaniem dokonanej oceny punktowej strategii, stanowią więc ważny rezultat podjętej pracy badawczej. Analizując te informacje, należy wziąć pod uwagę, że są to oceny przeliczone przez wagi.

W tabeli 13 przedstawiono wyniki wszystkich obliczeń, a zatem sumę punktów wyróżników przypisanych do każdego podejścia dla każdej gminy oraz średnią arytmetyczną osobno dla stolic regionów, stolic subregionów, gmin aglomeracyjnych i gmin peryferyjnych, a także osobno dla wszystkich gmin łącznie. Tabela zawiera informacje, których interpretacja stanowi kluczowy dla artykułu rezultat badań. 
postulaty koncentrują się na określeniu swojej pozycji w sieci i wykorzystaniu sieci w rozwoju

postulaty koncentrują się na stworzeniu, wykreowaniu innowacji

postulaty koncentrują się na wykorzystaniu własnych zasobów, głównie niematerialnych, budowaniu marki, kompetencji stanowiących wartość dla mieszkańców i obecnych przedsiębiorców

postulaty koncentrują się na zwiększeniu udziału w rynku, poszukiwaniu uprzywilejowanej pozycji, na konkurentach i wyróżnianiu się

postulaty koncentrują się na wykorzystaniu własnych zasobów materialnych i lokalizacyjnych, na osiaganiu celów związanych z pozyskaniem inwestorów, nowych mieszkańców i turystów

w analizie SWOT budowane strategie koncentrują się na OT

w analizie SWOT budowane strategie koncentrują się na SW

analiza strategiczna koncentruje się na zasobach relacyjnych, powiązaniach z innymi gminami

analiza strategiczna koncentruje się na zasobach unikatowych (posiadanych innowacjach)

analiza strategiczna koncentruje się na zasobach i kompetencjach głównie niematerialnych mieszkańców, instytucji publicznych, przedsiębiorstw, zasobach

$$
\text { czynnych }
$$

analiza strategiczna koncentruje się na zasobach odróżniających, dostawcach, odbiorcach, konkurencji, nowych oferentach, substytutach

analiza strategiczna koncentruje się na zasobach materialnych, zasobach biernych

analiza strategiczna koncentruje się na czynnikach zewnętrznych

analiza strategiczna koncentruje się na czynnikach wewnętrznych

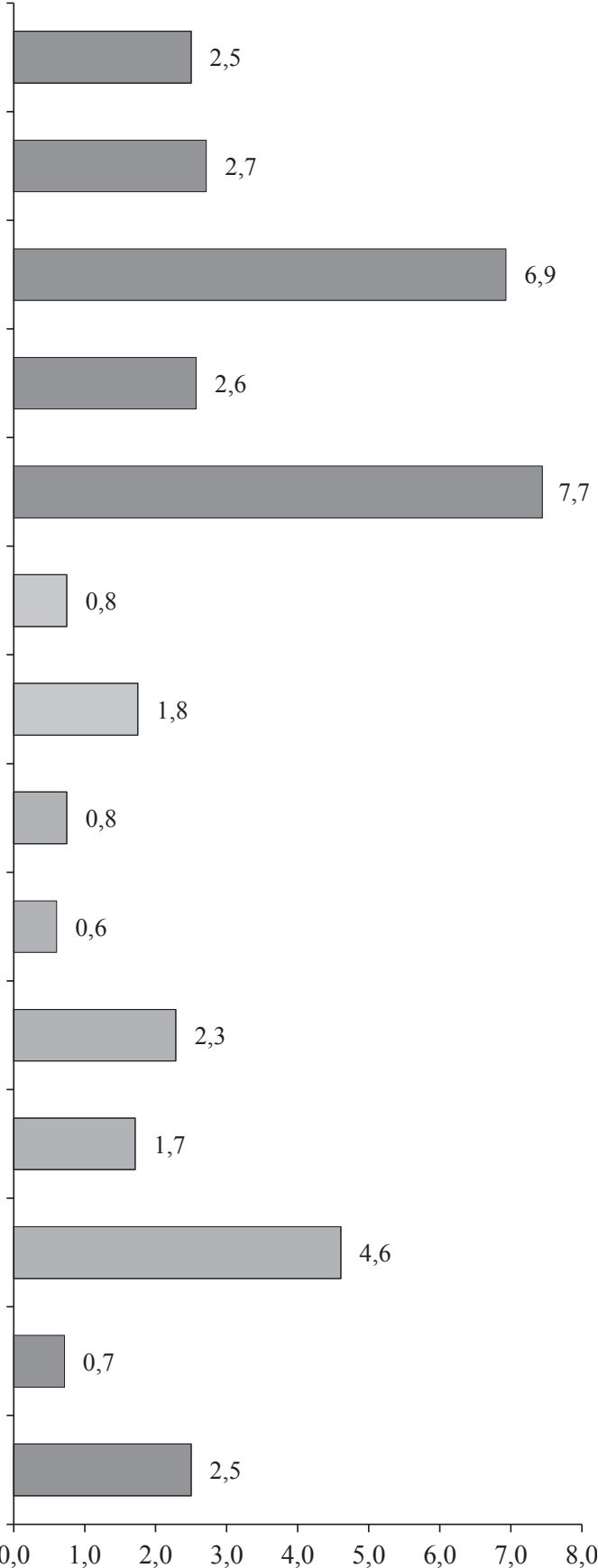

Rys. 1. Średnia arytmetyczna oceny przemnożonej przez wagę wszystkich wyróżników dla wszystkich badanych gmin łącznie

Źródło: opracowanie własne na podstawie przeprowadzonych badań empirycznych. 
Tabela 13. Oceny strategii badanych gmin według wszystkich wyróżników przypisanych do każdego podejścia

\begin{tabular}{|c|c|c|c|c|c|}
\hline \multirow[b]{2}{*}{ Gmina } & \multicolumn{5}{|c|}{ Podejście } \\
\hline & planistyczne & pozycyjne & zasobowe & innowacyjne & sieciowe \\
\hline $\begin{array}{l}\text { Średnia dla miast }- \text { stolic } \\
\text { regionów }\end{array}$ & 13,36 & 9,57 & 16,07 & 9,57 & 9,29 \\
\hline Łódź & 14 & 9 & 16 & 9 & 10 \\
\hline Wrocław & 13 & 12 & 15 & 13 & 12 \\
\hline Kraków & 13 & 11 & 18 & 14 & 9 \\
\hline Poznań & 13 & 10 & 17 & 12 & 11 \\
\hline Gdańsk & 12 & 10 & 16 & 6 & 9 \\
\hline Warszawa & 11 & 9 & 16 & 8 & 7 \\
\hline Lublin & 18 & 7 & 15 & 6 & 8 \\
\hline $\begin{array}{l}\text { Średnia dla miast - stolic } \\
\text { subregionów }\end{array}$ & 17,21 & 5,36 & 11,79 & 4,21 & 4,21 \\
\hline Sandomierz & 18 & 5 & 14 & 3 & 8 \\
\hline Legnica & 17 & 7 & 11 & 7 & 4 \\
\hline Częstochowa & 18 & 7 & 12 & 4 & 3 \\
\hline Koszalin & 17 & 4 & 9 & 6 & 2 \\
\hline Grudziądz & 17 & 6 & 14 & 6 & 5 \\
\hline Ciechanów & 18 & 4 & 10 & 3 & 4 \\
\hline Przemyśl & 17 & 5 & 14 & 1 & 4 \\
\hline $\begin{array}{l}\text { Średnia dla gminy } \\
\text { aglomeracyjnej }\end{array}$ & 18,14 & 3,79 & 13,29 & 2,07 & 2,64 \\
\hline Zgierz & 18 & 4 & 15 & 1 & 1 \\
\hline Kąty Wrocławskie & 18 & 4 & 14 & 3 & 7 \\
\hline Liszki & 17 & 5 & 12 & 2 & 4 \\
\hline Swarzędz & 20 & 4 & 15 & 2 & 4 \\
\hline Nowa Wieś Wielka & 17 & 3 & 14 & 2 & 2 \\
\hline Piaseczno & 19 & 4 & 14 & 5 & 1 \\
\hline Choroszcz & 20 & 4 & 11 & 1 & 1 \\
\hline $\begin{array}{l}\text { Średnia dla gminy } \\
\text { peryferyjnej }\end{array}$ & 17,57 & 4,29 & 12,71 & 3,29 & 2,71 \\
\hline Staszów & 15 & 4 & 16 & 3 & 1 \\
\hline Lwówek Śląski & 20 & 4 & 10 & 1 & 3 \\
\hline Gorlice & 17 & 5 & 15 & 6 & 4 \\
\hline Okonek & 18 & 4 & 15 & 1 & 4 \\
\hline Giżycko & 18 & 11 & 16 & 9 & 5 \\
\hline Przysucha & 18 & 1 & 10 & 1 & 1 \\
\hline Tyszowce & 20 & 3 & 10 & 4 & 3 \\
\hline $\begin{array}{l}\text { Średnia dla wszystkich } \\
\text { badanych gmin }\end{array}$ & 16,57 & 5,75 & 13,46 & 4,79 & 4,71 \\
\hline
\end{tabular}

Źródło: opracowanie własne na podstawie przeprowadzonych badań empirycznych. 
Biorąc pod uwagę wynik dla wszystkich badanych gmin łącznie, można zauważyć, że w dominuje w nich podejście planistyczne (rys. 2). Samorządy gminne na etapie planowania strategicznego koncentrują się przede wszystkim na czynnikach rozwojowych wewnętrznych, zasobach materialnych zarówno w analizie strategicznej, jak i w części postulatywnej. Diagnoza stanu polskich gmin obejmuje głównie inwentaryzację zasobów komunalnych wraz z podaniem wskaźników obrazujących korzystanie z tych zasobów (np. liczba uczniów w szkołach, liczba korzystających z infrastruktury wodociagowej i kanalizacyjnej). Zdecydowana większość opracowań diagnostycznych zawiera także podstawowe dane o ludności i przedsiębiorstwach. Czynniki rozwojowe zewnętrzne, których źródłem może być otoczenie polityczno-prawne, ekonomiczno-gospodarcze, społeczne czy technologiczne i środowiskowe, jest rzadko przedmiotem diagnozy. W analizie SWOT z racji narzuconego jej formatu wyodrębnia się, najczęściej hasłowo i ad hoc (bez potwierdzenia w danych) czynniki zewnętrzne. Szanse i zagrożenia zaliczane do tej kategorii czynników bardzo często utożsamiane są z postulatami. Te, które zostały prawidłowo, przynajmniej metodologicznie, zidentyfikowane, są mniej liczne niż mocne i słabe strony. Wychodząc nieco poza format chłodnej analizy, można stwierdzić, że gminy przez pryzmat diagnozy stanu sprawiają wrażenie organizacji wyizolowanych.

W strategiach, w których na poziomie diagnozy stanu poddano analizie otoczenie zewnętrzne, najczęściej zwraca się uwagę na aspekt polityczno-prawny. Wskazuje się uwarunkowania prawne realizacji zadań publicznych oraz uwarunkowania wynikające z zapisów strategii rozwoju regionów i kraju. Uwarunkowania ekonomiczno-gospodarcze są analizowane co najwyżej przez pryzmat sytuacji na rynku pracy, w tym szczególnie bezrobocia. Czynniki zewnętrzne społeczne rzadko są przedmiotem głębszej analizy. Zauważa się nieliczne trendy ogólnospołeczne, które mogą mieć wpływ na rozwój gminy. Podobnie jest z uwarunkowaniami technologicznymi i środowiskowymi. W żadnej z badanych strategii czynniki te nie zostały szerzej omówione.

Patrząc na opozycyjne z perspektywy oceny strategii pojęcia zasobów materialnych i niematerialnych, można stwierdzić, że dysproporcje w koncentrowaniu się gmin pomiędzy obiema kategoriami zasobów nie są tak duże, jak w przypadku czynników wewnętrznych i zewnętrznych. Należy jednak podkreślić, że gminy w analizie strategicznej skupiają uwagę przede wszystkim na zasobach materialnych, w tym szczególnie na infrastrukturze kubaturowej i liniowej, zasobach instytucjonalnych, uwarunkowaniach lokalizacyjnych i innych zasobach komunalnych - nieruchomościach gruntowych i zabudowanych. Zasoby niematerialne, jeśli już są objęte diagnoza, to raczej pobieżną. W rozdziałach, w których można by się spodziewać koncentracji właśnie na zasobach niematerialnych, dotyczących np. edukacji, kultury, polityki społecznej, dominują również zestawienia danych ilościowych obrazujących raczej wydajność infrastruktury. Kapitał społeczny analizowany jest najczęściej wyłącznie przez pryzmat ocen uczniów na egzaminach, wykształcenia mieszkańców według danych $\mathrm{z}$ ostatniego spisu powszechnego, liczby organizacji 
pozarządowych czy frekwencji wyborczej. Wizerunek czy, szerzej, marka gminy nie jest poddawana analizie. Podobnie rzecz się ma z kompetencjami pracowników administracji samorządowej, metodami zarządzania mieniem komunalnym i usługami. Można wymieniać długo, czego brakuje w diagnozach w odniesieniu do jakościowych analiz zasobów niematerialnych, warto jednak zaryzykować twierdzenie, że gminy mają świadomość istotności tych zasobów w rozwoju, czego wyraz daja w części postulatywnej strategii, trudno to jednak dostrzec w analizach strategicznych.

Rozpatrywane strategie w części, która zawiera wizję, misję, cele i zaplanowanie zadania, ujawniają odmienną niż w diagnozie relację między podejściem planistycznym i zasobowym. Jeśli weźmie się pod uwagę wyłącznie część postulatywną strategii gminnych, można odnieść wrażenie, że podejścia planistyczne i zasobowe do strategii gmin polskich są reprezentowane niemal w równym stopniu. Nieco bardziej gminy koncentrują się w celach i zaplanowanych zadaniach na zasobach materialnych i lokalizacyjnych niż na wykorzystaniu własnych zasobów niematerialnych (budowaniu marki, rozwijaniu kompetencji mieszkańców, przedsiębiorców czy pracowników samorządowych, poprawianiu jakości świadczonych usług). Nie są to jednak różnice duże. Z łatwością można dostrzec nastawienie na obie kategorie zasobów w niemalże każdej strategii.

Ocena części postulatywnej strategii miała duży wpływ na ostateczny wynik rozstrzygnięcia, jakie podejście do strategii dominuje w gminach. Zyskało znacznie podejście zasobowe, a biorąc pod uwagę, że część postulatywna strategii jest w o wiele większym stopniu bliska rzeczywistemu nastawieniu samorządów, można ostatecznie uznać, że podejście zasobowe ustępuje, choć nie zasadniczo, podejściu planistycznemu.

Podejścia pozycyjne, innowacyjne i sieciowe do strategii, jak wynika z analizy strategii, nie są istotne dla gmin. W części diagnostycznej uwidacznia się mocniej podejście pozycyjne niż innowacyjne i sieciowe. Wynika to przede wszystkim $\mathrm{z}$ tego, że gminy stosunkowo często porównują się z innymi gminami i szukają wyróżników wśród konkurencji. Konfrontacja z innymi gminami rzadko jednak staje się typową analizą benchmarkingową. Jednostki samorządu terytorialnego, z którymi porównują się gminy, często nie są identyfikowane jako konkurencja. Nie definiuje się przynajmniej zakresu potencjalnego konkurowania. Można stwierdzić, że porównanie jest wykonywane raczej na potrzeby interpretacji własnej sytuacji (co bez odniesienia do danych dla jednostek podobnej wielkości byłoby trudniejsze), bez konsekwencji w określeniu własnej pozycji konkurencyjnej.

W części postulatywnej podejścia pozycyjne, innowacyjne i sieciowe są w równym stopniu ujawnione, ale należy zaznaczyć, że jest to równie małe podobieństwo. Postulaty, które wskazywałyby na przykład na budowanie strategii różnicowania, należą do nielicznych. Na poziomie ogólnikowych deklaracji zawartych w strategii można zauważyć chęć zbudowania przewagi konkurencyjnej pod jakimś względem, jednak zazwyczaj w celach i zadaniach oraz ich opisach nie znajduje się rozwinięcia tych deklaracji. 
Podobnie rzecz ma się z podejściami innowacyjnym i sieciowym. Ogólnikowe deklaracje, najczęściej zapisane w wizji rozwoju czy swego rodzaju preambułach do celów i zadań, mówią o nastawieniu na innowacje oraz współpracę międzygminną lub międzysektorową, jednak niewiele celów i zadań jest temu poświęconych. W wielu strategiach o innowacjach wspomina się wyłącznie w kontekście oczekiwań, że na terenie gminy będą inwestować innowacyjne przedsiębiorstwa. Odniesienia do rozwoju innowacji w usługach publicznych są bardzo rzadkie. W diagnozie zupełnie pomija się ten aspekt, a w części postulatywnej marginalizuje się go lub również pomija.

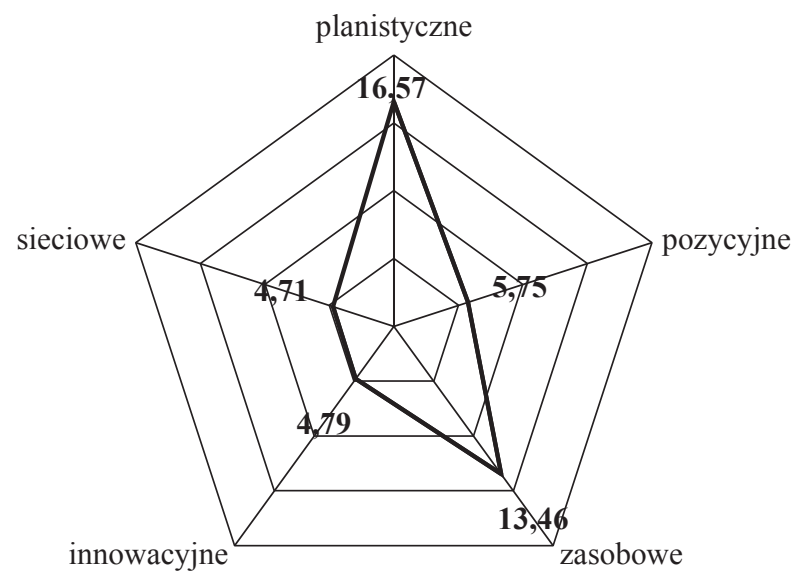

Rys. 2. Średnia punktów uzyskanych w badaniu w podziale na podejście strategiczne dla wszystkich badanych gmin

Źródło: opracowanie własne na podstawie przeprowadzonych badań empirycznych.

Wnioski z przeprowadzonych indywidualnych wywiadów pogłębionych potwierdzają wyniki analizy treści strategii gminnych. Szczegółowo omówiono je w tab. 14.

Ocena dokumentów strategicznych gmin pod kątem podejścia do strategii ujawniła zróżnicowanie pomiędzy gminami. Na potrzeby prowadzonych badań gminy zostały podzielone na cztery kategorie: duże miasta - stolice regionów, średnie miasta - stolice subregionów, gminy podmiejskie - aglomeracyjne, gminy oddalone od większych ośrodków miejskich - peryferyjne.

Duże miasta - stolice regionów odróżnia od gmin z innych kategorii to, że dominuje w nich podejście zasobowe (rys. 3). W odniesieniu do średniej dla wszystkich gmin łącznie wynik oceny dla dużych miast dał odwrotną relację między podejściem planistycznym i zasobowym. Podejście zasobowe ujawnia się przede wszystkim w części postulatywnej strategii. Bardzo silne nastawienie na zasoby niematerialne, w tym kompetencje kapitału społecznego, markę miasta, innowacje w usługach publicznych, zasoby relacyjne, poprawę jakości świadczonych usług, widoczne 
w strategiach dużych miast nie ujawnia się w pozostałych gminach. Nastawienie dużych miast na rozwój zasobów niematerialnych, kompetencji itd. można zaobserwować wyraźnie w warstwie językowej sformułowanych celów i zadań. Dominuje tam perspektywa mieszkańców i przedsiębiorców, a nie bezkontekstowy rozwój

Tabela 14. Wyniki przeprowadzonych indywidualnych wywiadów pogłębionych z ekspertami zajmującymi się planowaniem strategicznym w samorządach gminnych

\begin{tabular}{|c|c|}
\hline Pytanie kwestionariuszowe & Uzyskane odpowiedzi \\
\hline 1 & 2 \\
\hline $\begin{array}{l}\text { 1. Gminy w analizie strategicznej (diagnozie) } \\
\text { koncentrują się głównie na czynnikach } \\
\text { wewnętrznych, a zdecydowanie rzadziej na } \\
\text { czynnikach zewnętrznych. Czy Pani/Pana zdaniem } \\
\text { jest to prawidłowy wniosek? } \\
\text { a) zdecydowanie się nie zgadzam, } \\
\text { b) nie zgadzam się, } \\
\text { c) zgadzam się, } \\
\text { d) zdecydowanie się zgadzam. } \\
\text { Proszę o uzasadnienie odpowiedzi i/lub komentarz } \\
\text { odnośnie do wniosku }\end{array}$ & $\begin{array}{l}\text { Zgadzam się: } 2 \text { odpowiedzi } \\
\text { Zdecydowanie się zgadzam: } 3 \text { odpowiedzi } \\
\text { Respondenci potwierdzili wniosek z analizy } \\
\text { treści strategii. Wskazali, że czynniki } \\
\text { wewnętrzne są lepiej rozpoznane, dane } \\
\text { gromadzone przez administrację samorządową } \\
\text { w większym zakresie dotyczą zasobów } \\
\text { własnych. Na zasoby własne gminy mają } \\
\text { większy wpływ niż na czynniki zewnętrzne, } \\
\text { stąd większe zainteresowanie analizą } \\
\text { czynników wewnętrznych }\end{array}$ \\
\hline $\begin{array}{l}\text { 2. Gminy w analizie strategicznej (diagnozie) } \\
\text { koncentrują się głównie na zasobach materialnych } \\
\text { (infrastrukturze, budynkach, instytucjach, } \\
\text { zasobach przyrodniczych itp.), a mniej na } \\
\text { zasobach niematerialnych (kompetencjach } \\
\text { zasobów ludzkich, marce, jakości usług itp.). Czy } \\
\text { Pani/Pana zdaniem jest to prawidłowy wniosek? } \\
\text { a) zdecydowanie się nie zgadzam, } \\
\text { b) nie zgadzam się, } \\
\text { c) zgadzam się, } \\
\text { d) zdecydowanie się zgadzam. } \\
\text { Proszę o uzasadnienie odpowiedzi i/lub komentarz } \\
\text { odnośnie do wniosku }\end{array}$ & $\begin{array}{l}\text { Zgadzam się: } 5 \text { odpowiedzi } \\
\text { Respondenci potwierdzili wniosek z analizy } \\
\text { treści strategii. Zauważyli, że podejście to } \\
\text { zmienia się w ostatnich latach i przedmiotem } \\
\text { zainteresowania w planowaniu strategicznym } \\
\text { w coraz większym stopniu są zasoby } \\
\text { niematerialne, choć nadal gminy chętniej } \\
\text { zajmują się zasobami materialnymi. Związane } \\
\text { to jest między innymi z oczekiwaniem } \\
\text { społecznym dotyczącym rozwoju infrastruktury } \\
\text { liniowej }\end{array}$ \\
\hline $\begin{array}{l}\text { 3. W diagnozie w niewielkim zakresie } \\
\text { analizie poddawane są zasoby odróżniające } \\
\text { od potencjalnych konkurentów, gminy rzadko } \\
\text { koncentrują się na porównaniu własnych zasobów } \\
\text { z zasobami konkurencyjnych gmin, porównania } \\
\text { z innymi raczej ograniczają się do porównania } \\
\text { wskaźników sytuacji społeczno-gospodarczej. Czy } \\
\text { Pani/Pana zdaniem jest to prawidłowy wniosek? } \\
\text { a) zdecydowanie się nie zgadzam, } \\
\text { b) nie zgadzam się, } \\
\text { c) zgadzam się, } \\
\text { d) zdecydowanie się zgadzam. } \\
\text { Proszę o uzasadnienie odpowiedzi i/lub komentarz } \\
\text { odnośnie do wniosku }\end{array}$ & $\begin{array}{l}\text { Zgadzam się: } 4 \text { odpowiedzi } \\
\text { Zdecydowanie się zgadzam: 1 odpowiedź } \\
\text { Respondenci potwierdzili wniosek z analizy } \\
\text { treści strategii. Zauważyli, że w diagnozie } \\
\text { można spotkać odniesienia do konkurentów, } \\
\text { którymi są inne gminy, sąsiednie lub podobnej } \\
\text { wielkości, jednak odniesienia te dotyczą } \\
\text { przede wszystkim porównania ogólnej sytuacji } \\
\text { społeczno-gospodarczej. Bardzo rzadko lub } \\
\text { w ogóle nie spotyka się analizy porównawczej } \\
\text { konkretnych zasobów czy produktów gmin (jak } \\
\text { usługi, grunty inwestycyjne itp.) }\end{array}$ \\
\hline
\end{tabular}


Tabela 14, cd.

\begin{tabular}{|c|c|}
\hline 1 & 2 \\
\hline $\begin{array}{l}\text { 4. Bardzo rzadko w diagnozie gminy analizują } \\
\text { zasoby unikatowe - innowacyjne oraz zasoby } \\
\text { relacyjne, tj. zakres i jakość powiązań } \\
\text { z innymi gminami i podmiotami spoza sektora } \\
\text { samorządowego, które mogłyby być wykorzystane } \\
\text { do budowania przewagi konkurencyjnej } \\
\text { i osiaggania efektu synergii. Czy Pani/Pana } \\
\text { zdaniem jest to prawidłowy wniosek? } \\
\text { a) zdecydowanie się nie zgadzam, } \\
\text { b) nie zgadzam się, } \\
\text { c) zgadzam się, } \\
\text { d) zdecydowanie się zgadzam. } \\
\text { Proszę o uzasadnienie odpowiedzi i/lub komentarz } \\
\text { odnośnie do wniosku }\end{array}$ & $\begin{array}{l}\text { Zgadzam się: } 4 \text { odpowiedzi } \\
\text { Zdecydowanie się zgadzam: } 1 \text { odpowiedź } \\
\text { Respondenci potwierdzili wniosek z analizy } \\
\text { treści strategii. Wskazali, że w ostatnich latach } \\
\text { rośnie świadomość administracji samorządowej } \\
\text { odnośnie do potrzeby analizowania zasobów } \\
\text { innowacyjnych i relacyjnych, wciąż jednak jest } \\
\text { ona mała, a w zapisach strategii w diagnozie } \\
\text { rzadko poświęca się tym zasobom uwagę }\end{array}$ \\
\hline $\begin{array}{l}\text { 5. W analizie SWOT gminy skupiają się } \\
\text { głównie na czynnikach wewnętrznych, mocnych } \\
\text { i słabych stron zwykle wymienia się więcej niż } \\
\text { szans i zagrożeń. Czy Pani/Pana zdaniem jest to } \\
\text { prawidłowy wniosek? } \\
\text { a) zdecydowanie się nie zgadzam, } \\
\text { b) nie zgadzam się, } \\
\text { c) zgadzam się, } \\
\text { d) zdecydowanie się zgadzam. } \\
\text { Proszę o krótkie uzasadnienie odpowiedzi i/lub } \\
\text { komentarz odnośnie do wniosku }\end{array}$ & $\begin{array}{l}\text { Zgadzam się: } 4 \text { odpowiedzi } \\
\text { Zdecydowanie się zgadzam: } 1 \text { odpowiedź } \\
\text { Respondenci potwierdzili wniosek z analizy } \\
\text { treści strategii. Argumentowali podobnie jak } \\
\text { w przypadku wniosku o koncentracji w analizie } \\
\text { strategicznej na czynnikach wewnętrznych, } \\
\text { wskazując, że są one lepiej rozpoznane } \\
\text { i odnoszą się najczęściej do zasobów, na które } \\
\text { gminy mają wpływ }\end{array}$ \\
\hline $\begin{array}{l}\text { 6. W części programowej strategii (wizja, cele, } \\
\text { działania) gminy koncentrują się częściej na } \\
\text { wykorzystaniu i powiększaniu własnych zasobów } \\
\text { materialnych (infrastruktury) niż na rozwijaniu } \\
\text { zasobów niematerialnych (kompetencji, marki). } \\
\text { Czy Pani/Pana zdaniem jest to prawidłowy } \\
\text { wniosek? } \\
\text { a) zdecydowanie się nie zgadzam, } \\
\text { b) nie zgadzam się, } \\
\text { c) zgadzam się, } \\
\text { d) zdecydowanie się zgadzam. } \\
\text { Proszę o uzasadnienie odpowiedzi i/lub komentarz } \\
\text { odnośnie do wniosku }\end{array}$ & $\begin{array}{l}\text { Nie zgadzam się: } 2 \text { odpowiedzi } \\
\text { Zgadzam się: } 2 \text { odpowiedzi } \\
\text { Zdecydowanie się zgadzam: } 1 \text { odpowiedź } \\
\text { Respondenci potwierdzili wniosek z analizy } \\
\text { treści strategii, choć odpowiedzi nie są tak } \\
\text { jednoznaczne jak w przypadku innych pytań. } \\
\text { Dwóch ekspertów nie zgodziło się } \\
\text { z wnioskiem. Należy wskazać, że wnioski } \\
\text { z analizy treści strategii również nie } \\
\text { wskazywały na dużo większą koncentrację } \\
\text { gmin w części programowej strategii na } \\
\text { zasobach materialnych niż na niematerialnych. } \\
\text { Wszyscy respondenci są przekonani, że } \\
\text { w większych miastach świadomość co do } \\
\text { konieczności skupienia się na zasobach } \\
\text { niematerialnych jest większa niż w mniejszych } \\
\text { jednostkach. Zauważają, że generalnie } \\
\text { w ostatnich latach większy nacisk, choć } \\
\text { nadal zbyt mały, kładziony jest na zasoby } \\
\text { niematerialne, które we współczesnym świecie } \\
\text { odgrywają większą rolę z punktu widzenia } \\
\text { rozwoju lokalnego niż zasoby materialne }\end{array}$ \\
\hline
\end{tabular}




\begin{tabular}{|l|l|}
\hline \multicolumn{1}{|c|}{1} & \multicolumn{1}{|c|}{2} \\
\hline 7. W części programowej strategii (poprzez & Zgadzam się: 3 odpowiedzi \\
konkretne zapisy) gminy rzadko koncentrują się & Zdecydowanie się zgadzam: 2 odpowiedzi \\
na tym, aby zdobyć przewagę nad konkurentami & Respondenci potwierdzili wniosek z analizy \\
i na rozwijaniu zasobów, którymi będą się & treści strategii. W ich opinii konkurenci rzadko \\
wyróżniać wśród konkurentów. Konkurenci & są punktem odniesienia dla formułowanych \\
nie są punktem odniesienia w formułowaniu & celów i działan. Większe miasta czéściej \\
celów i działań. Czy Pani/Pana zdaniem jest to & pozycjonują się na tle konkurentów, \\
prawidłowy wniosek? & w tym metropolii europejskich, dlatego \\
a) zdecydowanie się nie zgadzam, & w ich strategiach można odnaleźć częściej \\
b) nie zgadzam się, & odniesienia do konkurentów \\
c) zgadzam się, & \\
d) zdecydowanie się zgadzam. & \\
Proszę o uzasadnienie odpowiedzi i/lub komentarz & \\
odnośnie do wniosku & \\
\hline 8. W części programowej gminy również rzadko & \\
formułują cele i działania, w których zapisane & Zgadzam się: 4 odpowiedzi \\
byłoby rozwijanie czy kreowanie innowacji oraz & Zdecydowanie się zgadzam: 1 odpowiedź \\
wykorzystanie sieci powiązań z innymi gminami & Respondenci potwierdzili wniosek z analizy \\
lub podmiotami z sektorów pozasamorządowych. & w administegii. Mimo rosnącej świadomości \\
Czy Pani/Pana zdaniem jest to prawidłowy & do konieczności rozwijąania innowacji oraz \\
wniosek? & współpracy pomiędzy samorządami gminy nie \\
a) zdecydowanie się nie zgadzam, & potrafią przekuć tego na konkretne postulaty. \\
b) nie zgadzam się, & Jeśli już się takie pojawiają, to raczej na \\
c) zgadzam się, & poziomie wizji lub celów, rzadko na poziomie \\
d) zdecydowanie się zgadzam. & konkretnych działań zapisanych w strategiach \\
Proszę o uzasadnienie odpowiedzi i/lub komentarz & \\
odnośnie do wniosku & \\
\hline
\end{tabular}

Źródło: opracowanie własne.

infrastruktury. W części diagnostycznej i analizie SWOT cechy podejścia zasobowego nie przeważają nad cechami podejścia planistycznego, choć intensywność ich występowania jest dużo większa niż w przypadku innych badanych gmin. W analizie strategicznej stolic regionów dominują odniesienia do czynników wewnętrznych, choć można również znaleźć przypadki takich strategii, w których otoczenie jest analizowane stosunkowo szeroko. W analizie SWOT (która często nie jest wykonywana na potrzeby dużych miast) także przeważają czynniki wewnętrzne. W diagnozie stanu stolic regionów w większym zakresie analizuje się zasoby materialne i uwarunkowania lokalizacyjne niż zasoby niematerialne, ale trzeba zaznaczyć, że dysproporcje te nie są duże.

W części postulatywnej strategii dużych miast można dostrzec także stosunkowo silne nastawienie na rozwijanie zasobów unikatowych, w tym innowacji w usługach publicznych. Nieco mniej wyraźnie widać to w diagnozie i analizie SWOT.

Do podobnych wniosków można dojść w odniesieniu do cech podejścia sieciowego. Duże miasta silnie akcentują nastawienie na budowanie relacji z innymi mia- 


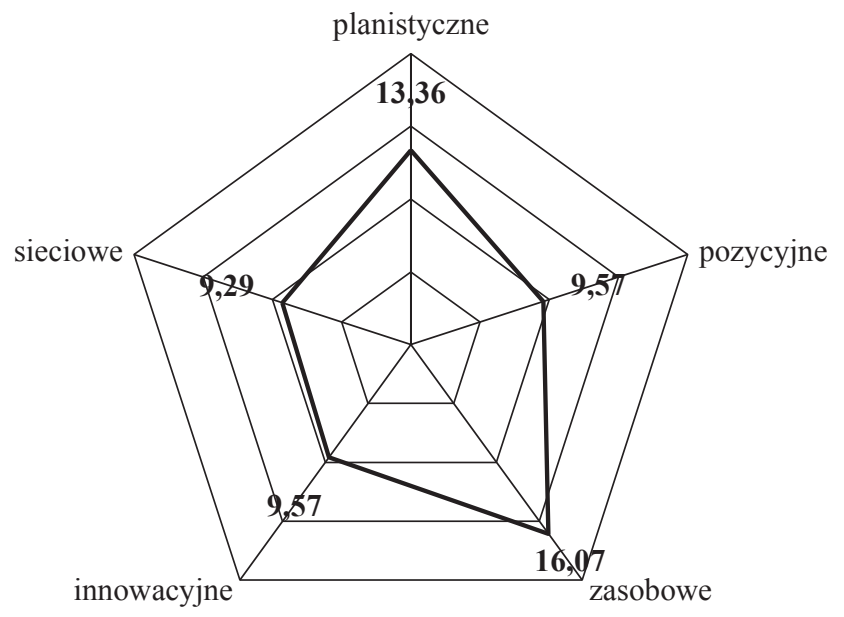

Rys. 3. Średnia punktów uzyskanych w badaniu w podziale na podejście strategiczne dla miast - stolic regionów

Źródło: opracowanie własne na podstawie przeprowadzonych badań empirycznych.

stami i sektorami (przedsiębiorstwami, wyższymi uczelniami, organizacjami pozarządowymi), choć w diagnozie brakuje analiz z tego zakresu.

Podejście pozycyjne ujawnia się z podobną siłą jak podejście innowacyjne i sieciowe. W części postulatywnej można dostrzec częste odniesienia do konkurentów, do których zalicza się inne duże ośrodki miejskie, nie tylko polskie. W diagnozie $\mathrm{z}$ kolei zamieszczono analizy porównawcze z innymi miastami. Widoczne są również inne cechy podejścia pozycyjnego, takie jak: koncentracja na dostawcach usług publicznych (ich potencjale), zbadanych przez socjologów potrzebach mieszkańców rozumianych jako odbiorców.

Średniej wielkości miasta ujawniają podejście do strategii podobne do podejścia cechującego średnio wszystkie gminy. Cechy planistycznego podejścia można zaobserwować zarówno w części diagnostycznej strategii, jak i wśród postulatów (rys. 4). Dominują nad cechami podejścia zasobowego, które również stosunkowo intensywnie występuja, oraz znacznie przeważają nad wyróżnikami podejścia pozycyjnego, innowacyjnego i sieciowego. Podejście zasobowe jest bardzo słabo widoczne w diagnozie stanu i analizie SWOT. Miasta średniej wielkości koncentrują się w tych częściach na zasobach materialnych i wewnętrznych czynnikach rozwojowych. Analiza zasobów niematerialnych jest bardzo słabo widoczna w diagnozie. Biorąc pod uwagę to, na jakich zasobach koncentrują się samorządy średnich ośrodków miejskich, można zauważyć, że intensywniej występują w analizie strategicznej cechy podejścia pozycyjnego niż zasobowego. Miasta średniej wielkości stosunkowo często porównują się z innymi miastami podobnej wielkości i analizują swoją konkurencyjność m.in. poprzez zasoby gruntowe. W części postulatywnej podejście 


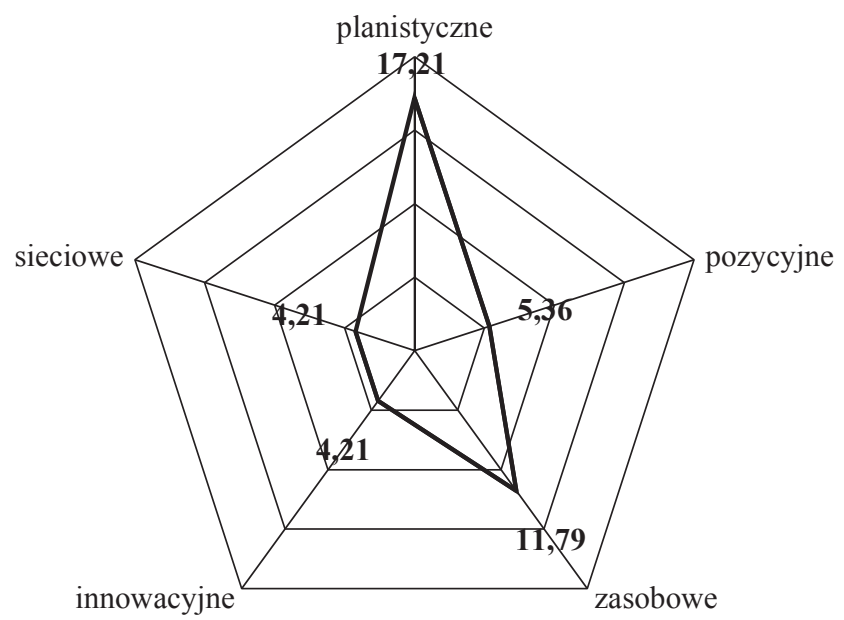

Rys. 4. Średnia punktów uzyskanych w badaniu w podziale na podejście strategiczne dla badanych miast - stolic subregionów

Źródło: opracowanie własne na podstawie przeprowadzonych badań empirycznych.

pozycyjne ustępuje innym, a jego wyróżniki występują z najmniejszą intensywnością wraz z wyróżnikami podejścia sieciowego. Wśród postulatów można zaobserwować najczęściej cechy podejścia planistycznego, czyli koncentrację na rozwoju zasobów materialnych, wykorzystaniu lokalizacji do pozyskiwania nowych mieszkańców, których ubywa, inwestorów i turystów. Perspektywa rozwoju zasobów innowacyjnych jest słabo widoczna w celach i zaplanowanych zadaniach.

Gminy aglomeracyjne w przeprowadzonym badaniu wykazały się cechami dość zaskakującymi (rys. 5). Gminy podmiejskie cechuje w największym stopniu spośród uwzględnionych $\mathrm{w}$ badaniu podejście planistyczne. W diagnozie koncentrują się bardzo mocno na zasobach materialnych i warunkach lokalizacyjnych. Diagnoza stanu nasycona jest inwentaryzacją infrastruktury liniowej i kubaturowej, analizami zasobów instytucjonalnych, danymi obrazującymi wydajność infrastruktury, w tym wskaźniki dotyczące korzystających z infrastruktury. Jednocześnie analiza zasobów niematerialnych jest pobieżna, a zasoby odróżniające, dostawcy i odbiorcy usług, zasoby innowacyjne i sieciowe nie są w ogóle brane pod uwagę lub w bardzo małym zakresie.

W części postulatywnej można zauważyć, że zdecydowanie więcej uwagi samorządy gmin aglomeracyjnych poświęcają rozwijaniu zasobów niematerialnych, w tym kompetencji mieszkańców, wizerunkowi, promocji, poprawianiu jakości świadczonych usług publicznych. W związku z tym obok podejścia planistycznego, wciąż dominującego, ujawnia się silniej podejście zasobowe. Cechy podejścia pozycyjnego są ledwie zauważane wśród postulatów, a o rozwoju zasobów innowacyjnych w usługach publicznych czy zasobów relacyjnych nie mówi się nic lub niewiele. 


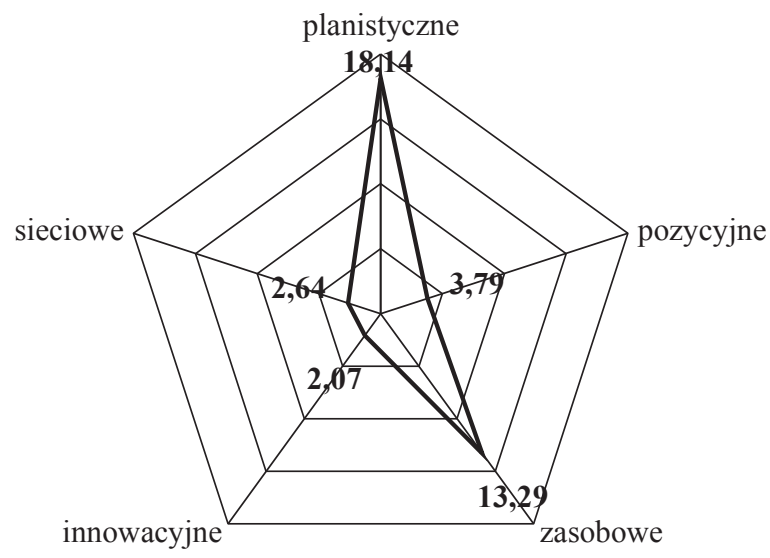

Rys. 5. Średnia punktów uzyskanych w badaniu w podziale na podejście strategiczne dla badanych gmin aglomeracyjnych

Źródło: opracowanie własne na podstawie przeprowadzonych badań empirycznych.

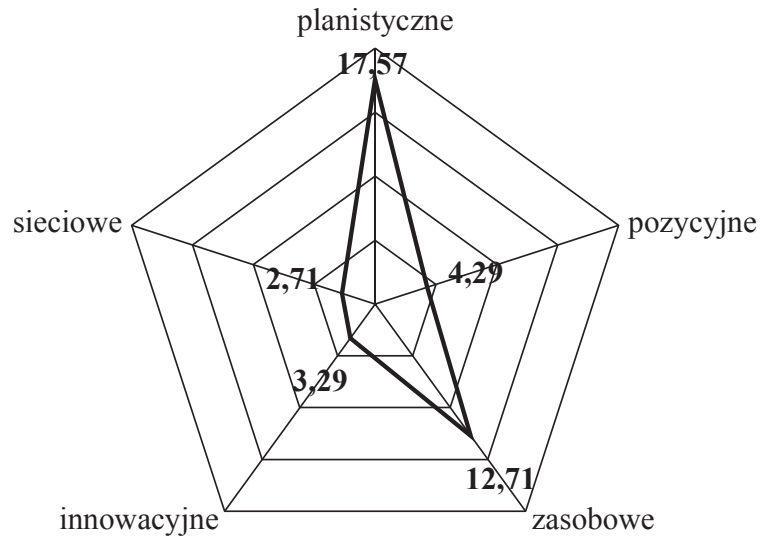

Rys. 6. Średnia punktów uzyskanych w badaniu w podziale na podejście strategiczne dla badanych gmin peryferyjnych

Źródło: opracowanie własne na podstawie przeprowadzonych badań empirycznych.

Rozkład cech podejść do strategii, które można zaobserwować w dokumentach strategicznych gmin peryferyjnych, jest podobny do tego, jaki charakteryzował gminy aglomeracyjne (rys. 6). W gminach peryferyjnych również dominuje podejście planistyczne, nastawienie na rozwijanie głównie zasobów materialnych i koncentracja na nich, a także na czynnikach wewnętrznych w diagnozie. Cechy podejścia zasobowego są słabo widoczne w części analizy strategicznej, ale silniej ujawniają się w części postulatywnej. Podejście pozycyjne nieco wyraźniej można dostrzec w diagnozie, ale marginalnie w części postulatywnej. Gminy peryferyjne, choć nieco bar- 
dziej niż aglomeracyjne wykazują się cechami podejścia innowacyjnego i sieciowego, to w obu przypadkach zapisy dokumentów źródłowych o tym świadczące są bardzo lakoniczne.

\section{Wnioski i podsumowanie}

Nie ma podstaw do odrzucenia hipotezy głównej badań dotyczącej dominacji planistycznego podejścia do strategii i w mniejszym stopniu podejścia zasobowego. Interpretując wyniki badań, omówiono już, w jaki sposób się to przejawia. Podejścia pozycyjne, innowacyjne i sieciowe może nie tyle są obce samorządom gminnym, ile raczej nie upowszechniły się wystarczająco mocno. Samorządy gminne, jak można przypuszczać na podstawie obserwacji działalności gmin niezależnej od przeprowadzonych badań, dostrzegają korzyści związane z rentą innowacyjną i sieciową, jednak nie potrafią podjąć wyzwania polegającego na budowaniu takich zasobów, aby mogły osiagać cele rozwojowe za pomocą jednej lub drugiej renty. Podejście pozycyjne może być z kolei postrzegane jako niezgodne z naturą gminy, której główne zadania rozumiane są jako zaspokajanie potrzeb interesariuszy wewnętrznych, a nie identyfikowanie konkurentów w otoczeniu oraz poszukiwanie przewagi konkurencyjnej nad nimi.

W przypadku hipotezy dotyczącej nastawienia dużych miast na podejście innowacyjne i sieciowe w większym stopniu niż innych typów gmin również nie znaleziono podstaw do jej odrzucenia. Duże miasta - stolice regionów w dużo większym stopniu niż gminy innego typu przejawiają cechy podejścia innowacyjnego. Pierwszą i chyba trafną myślą uzasadniającą ten fakt jest to, że duże miasta mają łatwy, a w stosunku na przykład do gmin peryferyjnych bardzo łatwy dostęp do kapitału intelektualnego wyższych uczelni, ośrodków naukowo-badawczych czy instytucji otoczenia biznesu. W takim środowisku idee rozprzestrzeniają się szybko i trafiają na podatny grunt chłonnych nowości samorządowców. Dostęp do nowych technologii już tak specjalnie nie różnicuje gmin większych i mniejszych, ośrodków uniwersyteckich i gmin peryferyjnych. Należy jednak pamiętać, że badanie zostało przeprowadzone na dokumentach źródłowych, jakimi są strategie rozwoju, a zatem mowa jest o rozprzestrzenianiu się idei, a nie technologii. Obserwując praktykę zarządzania gminami, dostrzega się, że w stosowaniu technologii i rozwiązań innowacyjnych, czyli w budowaniu zasobów innowacyjnych, średnie miasta wcale nie ustępują stolicom regionów. $Z$ jakichś powodów różnice te dostrzec jednak można na poziomie planowania strategicznego. Podejście sieciowe również występuje intensywniej w dużych miastach niż w innego typu gminach. W dużych miastach częściej dostrzega się korzyści wynikające z sieci międzysektorowych tworzonych np. przez administrację publiczną i ośrodki naukowe. Duże miasta również deklarują chęć realizacji działań rozwojowych we współpracy ze swoimi mniejszymi sąsiadami tworzącymi obszar funkcjonalno-przestrzenny, którego rdzeniem są duże miasta. 
Trudno odpowiedzieć na pytanie, dlaczego gminy aglomeracyjne podobne deklaracje względem miast - rdzeni aglomeracji składają o wiele rzadziej. Hipotezy, że gminy podmiejskie $\mathrm{w}$ aglomeracjach $\mathrm{w}$ większym stopniu przejawiają $\mathrm{w}$ planowaniu strategicznym cechy podejścia sieciowego ze względu na silne powiązania z innymi gminami wewnątrz aglomeracji, nie można było w toku zrealizowanych badań potwierdzić. Gminy aglomeracyjne są bardzo skupione na sobie. Jesteśmy świadkami intensywnego rozwoju tych jednostek i dużych zmian zachodzących na ich terytoriach. W szybkim tempie do tych gmin napływają nowe inwestycje w budownictwo mieszkaniowe, a wraz z nimi - nowi mieszkańcy. Duże firmy o profilu przemysłowo-magazynowym chętnie sytuują się w pobliżu dużych miast właśnie na terenie gmin aglomeracyjnych. Być może to jest powód utraty zainteresowania rentą sieciową w sytuacji pozostawania w stanie ciagłego gaszenia pożarów.

Podejście planistyczne i podejście zasobowe to podejścia dominujące nad innymi. Warto jednak zastanowić się nad odpowiedzią na pytanie, dlaczego tak jest w samorządach gminnych, bo mogą to być inne przyczyny niż te, które dotyczą przedsiębiorstw. Przede wszystkim należy zdać sobie sprawę z tego, że gminy poprzez swoje struktury zarządcze mają większy bezpośredni wpływ na zasoby materialne niż na niematerialne, zwłaszcza jeśli wśród głównych zasobów niematerialnych umieścić kompetencje mieszkańców i przedsiębiorców należących do grupy interesariuszy wewnętrznych gminy. Menedżer w przedsiębiorstwie poprzez realizację strategii personalnej może mieć bezpośredni wpływ na zwiększanie wiedzy i usprawnianie umiejętności pracowników. Menedżerowie w administracji samorządowej mogą tak wpływać jedynie na pracowników administracji, mają jednak dużo mniejsze możliwości kształtowania kompetencji mieszkańców czy przedsiębiorców.

W strategiach gminy powinny pojawić się również obszerniej elementy myślenia sieciowego (Chrisidu-Budnik, 2020; Kołsut, 2015). Szerzej także winny być implementowane rozwiązania pochodzące z koncepcji Industry 4.0 związane nie tylko z cyfryzacją administracji, ale przede wszystkim ze zmianą sposobu myślenia na koncept myślenia w kategorii smart (Angelidou, 2016; Schiavone, Appio, Mora i Risitano, 2020).

Samorządy gminne są skoncentrowane na zasobach własnych i czynnikach wewnętrznych. Gmina jest jednostką o konkretnych granicach terytorialnych. Można powiedzieć, że przedsiębiorstwo również, jednak różnica polega na tym, że gmina jest też prawnie ograniczona co do mieszkańców, przedsiębiorców czy organizacji pozarządowych, których pomnażanie korzyści jest celem gminy. Przedsiębiorstwo, przynajmniej teoretycznie, może mieć interesariuszy na całym świecie i w ogromnej liczbie (np. Google, Facebook, Microsoft). Gmina nie może zgodnie z prawem zaspokajać potrzeb nie swoich mieszkańców. Biorąc to pod uwagę, można zrozumieć, dlaczego gminy niechętnie wychodzą poza swoje granice. $Z$ pewnością jest tam wiele rzeczy, które mają wpływ na ich rozwój, ale uwaga samorządów jest odciągana od nich i kierowana do wewnątrz. 
Gmina działa w bardzo ściśle określonych ramach prawnych. Przedsiębiorstwo musi przestrzegać również wielu przepisów prawnych, ale nic je nie ogranicza co do zakresu działalności czy decyzji biznesowych. $Z$ dnia na dzień przedsiębiorstwo może podjąć decyzję o zupełnym przeprofilowaniu działalności i przynajmniej prawnie nie ma ku temu żadnych przeszkód. Trudno sobie wyobrazić, że takiego zwrotu dokona gmina, że porzuci swoje obowiązki ustawowe, w których wyliczono wiele konkretnych zadań, i poświęci uwagę strategii błękitnego oceanu. To kolejne uzasadnienie tego, dlaczego gminy są mniej zainteresowane otoczeniem i nadarzającymi się szansami niż potencjałem wewnętrznym, a także eliminowaniem słabych stron i wzmacnianiem silnych.

Wśród dodatkowych wniosków z przeprowadzonych badań należy wskazać zaobserwowaną niespójność pomiędzy częścią diagnostyczną i postulatywną. W części diagnostycznej widać dużo większe skupienie na zasobach materialnych, w tym szczególnie na mieniu komunalnym (infrastrukturze kubaturowej i liniowej, instytucjach tworzących administrację samorządowa, gruntach). W części postulatywnej gminy chętniej zauważają mieszkańców i ich kompetencje, konieczność poprawiania funkcji zarządzania usługami publicznymi, budowania marki, tworzenia innowacji i sieciowania. To z pewnością dowodzi, że świadomość różnorodności rent ekonomicznych, na których można budować rozwój, jest dużo większa niż umiejętność zastosowania aparatu poznawczego dla zdiagnozowania, jak to zrobić. Może to niestety oznaczać, że czesść postulatywna będzie się rozmijać z realizacją zaplanowanych celów i zadań. Na etapie wdrażania może ujawnić się większa skłonność do podejścia planistycznego, opartego na sprawnym zarządzaniu głównie zasobami materialnymi i skupianiu się na wewnętrznych czynnikach rozwojowych.

$\mathrm{W}$ toku procesu badawczego poddano szczegółowej ocenie 28 strategii rozwoju gmin. Wnioski z oceny można uzupełnić o rekomendacje dla gmin, które będą stanowić użyteczny efekt podjętych badań.

Przede wszystkim podczas prac nad kolejnymi strategiami lub aktualizacjami obecnych gminy powinny przemyśleć, czy renta ekonomiczna, a mówiąc prościej, czy źródło przewagi konkurencyjnej, źródło sukcesu zostało odpowiednio zidentyfikowane, a następnie poddane analizie i przełożone na postulaty. Może niepokoić stosunkowo niski poziom koncentracji na niematerialnych zasobach gminy, które niewattpliwie w dobie globalizacji i rozwoju gospodarki opartej na wiedzy zyskują na znaczeniu. Niepokoi także małe zainteresowanie innowacjami w usługach publicznych. Niewykorzystane mogą być zasoby i potencjał relacyjny. W wielu dziedzinach, w których gminy świadczą usługi, np. w gospodarowaniu odpadami, zachodzą bardzo dynamiczne zmiany w otoczeniu, które pojedynczych graczy mogą niemile zaskoczyć. W sieci można sobie łatwiej poradzić z zagrożeniami.

Otoczenie jest bardzo słabo analizowane przez gminy. Zbytnie skupienie na zasobach własnych i czynnikach wewnętrznych może skutkować przegapieniem szans i niezauważaniem zagrożeń. Analizy otoczenia, czynników zewnętrznych powinny być znacznie szerzej wzięte pod uwagę w procesie planowania. 
Diagnoza stanu i część postulatywna powinny być spójne w treści. Analiza strategii gminnych wykazała, że postulaty są podejmowane bez wcześniejszej analizy potencjału, który mógłby być wykorzystany do realizacji zakładanych celów.

Należy zwiększyć w analizie strategicznej udział badań jakościowych i w większym zakresie pozyskiwać dane ze źródeł pierwotnych. Wykonywanie jedynie analizy desk research może skutkować tym, że istotne czynniki, głównie niematerialne, zostaną pominięte. W konsekwencji nawet jeśli w postulatach zostaną uwzględnione zasoby niematerialne, to zabraknie metod pomiaru oczekiwanej zmiany.

\section{Literatura}

Angelidou, M., (2016). Four European smart city strategies. International Journal of Social Science Studies, 4(4), 18-30.

Bembenek, B. i Piecuch, T. (2012). Przedsiębiorczy wymiar klastra. Zeszyty Naukowe Uniwersytetu Szczecińskiego, (719), Ekonomiczne Problemy Ustug, (940), 27-46.

Brol, R. (2004). Strategia rozwoju lokalnego. W: R. Brol (red.), Ekonomika i zarzqdzanie miastem. Wrocław: Wydawnictwo Akademii Ekonomicznej we Wrocławiu.

Chrisidu-Budnik, A. (2009). Administracja publiczna w strukturze sieciowej. W: Między tradycja a przyszłościq w nauce prawa administracyjnego, Księga jubileuszowa dedykowana Profesorowi Janowi Bociowi. Wrocław: Wydawnictwo Uniwersytetu Wrocławskiego.

Chrisidu-Budnik, A. (2010). Kontraktowe i relacyjne mechanizmy koordynacji w sieciach międzyorganizacyjnych. Przeglad Prawa i Administracji, 120(1), 403-412.

Drumaux, A. i Goethals, Ch. (2007). Strategic management: A tool for public management? An overview of the Belgian federal experience. International Journal of Public Sector Management, 20(7), 638-654.

Furmankiewicz, M. (2002). Funkcjonalno-przestrzenne sieci współpracy samorządów lokalnych. Studia Regionalne i Lokalne, 1(8), 5-24.

Gawroński, H. (2010). Zarzqdzanie strategiczne w samorzqdach lokalnych. Warszawa: Oficyna a Wolters Kluwer business.

Główny Urząd Statystyczny. (b.d.). Pobrano 5 kwietnia 2019 z https://bdl.stat.gov.pl

Grobelny, R. i Klupczyński, M. (2016). Centralizacja działalności w jednostkach samorządu terytorialnego z wykorzystaniem centrum usług wspólnych. W: I. Wieczorek (red.), Zarzadzanie w jednostkach samorzadu terytorialnego. Wybrane aspekty. Wrocław: Wydawnictwo Uniwersytetu Wrocławskiego.

Herbst, M. (red.). (2007). Kapitał ludzki i kapitat społeczny a rozwój regionalny. Warszawa: Wydawnictwo Naukowe Scholar.

Inteligentne miasto. (b.d.). Pobrano 9 maja $2019 \mathrm{z}$ https://pl.wikipedia.org/wiki/Inteligentne_miasto

Klasyfikacja NUTS w Polsce. (b.d.). Pobrano 5 kwietnia 2019 z https://stat.gov.pl/statystyka-regionalna/jednostki-terytorialne/klasyfikacja-nuts/klasyfikacja-nuts-w-polsce

Kołsut, B. (2015). Zinstytucjonalizowane sieci współdziałania międzygminnego w Polsce (Niepublikowana rozprawa doktorska). Poznań: Uniwersytet im. Adama Mickiewicza w Poznaniu. Pobrano 8 grudnia $2020 \mathrm{z}$ https://repozytorium.amu.edu.pl/handle/10593/13278.

Koncepcja Przestrzennego Zagospodarowania Kraju 2030. (b.d.). Uchwała nr 239 Rady Ministrów z dnia 13 grudnia 2011 r. (MP z 2012 r., poz. 252)

Kozak, M. W. (2014). Konflikty wokół nowego paradygmatu a rozwój regionalny Polski po 1990 roku. Nierówności Spoleczne a Wzrost Gospodarczy, 37(1/2014), 163-180. 
Kozak, M. W. (2016). Między starym i nowym paradygmatem - skutki dla rozwoju państw słabiej rozwiniętych w UE. W: K. Opolski i J. Górski (red.), Wyzwania integracji gospodarczej w Unii Europejskiej (s. 137-143). Warszawa: Wydział Nauk Ekonomicznych Uniwersytetu Warszawskiego.

Król, H. i Ludwiczyński, A. (2006). Zarzqdzanie zasobami ludzkimi. Tworzenie kapitału ludzkiego organizacji. Warszawa: Wydawnictwo Naukowe PWN.

Markowski, T. (1999). Zarzqdzanie rozwojem miast. Warszawa: Wydawnictwo Naukowe PWN.

Niemczyk, J. (2013). Strategia. Od planu do sieci. Wrocław: Wydawnictwo Uniwersytetu Ekonomicznego we Wrocławiu.

Niemczyk, J. (2014). Logika rozwoju strategii. Prace Naukowe Wałbrzyskiej Wyższej Szkoły Zarzqdzania i przedsiębiorczości, 27, Zarzadzanie Strategiczne, 67-75.

Niemczyk, J. i Latocha, W. (2014). Renta sieciowa a wartość przedsiębiorstwa. W: R. Borowiecki i T. Rojek (red.), Współczesne formy relacji międzyorganizacyjnych. Współpraca - kooperacjasieci (s. 139-145). Kraków: Fundacja Uniwersytetu Ekonomicznego w Krakowie.

Nowicka-Szczepańska, M. (2013). Koncepcja New Public Management jako nurt ekonomizujący w zarządzaniu jednostkami administracji samorządowej (wybrane aspekty). Prace Naukowe Watbrzyskiej Wyższej Szkoty Zarzadzania i Przedsiębiorczości, 24 (4), 95-107.

Obłój, K. (2014). Strategia organizacji. Warszawa: PWE.

Porter, M. E. (1992). Strategia konkurencji. Metody analizy sektorów i konkurentów. Warszawa: PWE.

Pytlak, M. (2010). Konkurencja i współpraca - komplementarne działania władz lokalnych (na przykładzie wybranych gmin zachodniego pasma aglomeracji warszawskiej). Rocznik Żyrardowski, VIII, 385-424.

Ratajczak, M. (2000). Infrastruktura a wzrost i rozwój gospodarczy. Ruch Prawniczy, Ekonomiczny i Socjologiczny, LXII(4), 83-102.

Saniuk, A., Saniuk, S. i Jakábová, M. (2012). Korzyści i bariery tworzenia klastrów przemysłowych w Polsce. Zeszyty Naukowe Uniwersytetu Szczecińskiego, (719), Ekonomiczne Problemy Usług, (94), 277-292.

Schiavone, F., Appio, F. P., Mora, L. i Risitano, M. (2020). The strategic, organizational, and entrepreneurial evolution of smart cities. International Entrepreneurship and Management Journal, 16(4), 1155-1165.

Stawasz, D. i Sikora-Fernandez, D. (2016). Koncepcja smart city a zarządzanie miastem. W: I. Wieczorek (red.), Zarzqdzanie w jednostkach samorzqdu terytorialnego. Wybrane aspekty (s. 73-93). Wrocław: Wydawnictwo Uniwersytetu Wrocławskiego.

Szaja, M. (2013). Konkurencyjność gmin pod względem struktury przestrzennej: na przykładzie gmin nadmorskich województwa zachodniopomorskiego. Zeszyty Naukowe Uniwersytetu Szczecińskiego, (794), Ekonomiczne Problemy Ustug, (108), 273-289.

Szromnik, A. (2011). Marketing terytorialny jako atrybut rynkowej orientacji miast oraz regionów. W: A. Grzegorczyk i A. Kochaniec (red.), Kreowanie wizerunku miast. Warszawa: Wyższa Szkoła Promocji.

Sztando, A. (2004). Instrumenty lokalnej polityki gospodarczej. W: R. Brol (red.), Ekonomika i zarzqdzanie miastem. Wrocław: Wydawnictwo Akademii Ekonomicznej we Wrocławiu.

Śleszyński, P. (2013). Delimitacja Miejskich Obszarów Funkcjonalnych stolic województw. Przegląd Geograficzny, 82(2), 173-197.

Światowiec-Szczepańska, J. (2012). Renta ekonomiczna a przewaga konkurencyjna przedsiębiorstwa. Ekonomista, (2), 203-226.

Świerk, J. (2016). Koncepcja interesariuszy w zarządzaniu strategią - analiza przypadku gminy Inowrocław. Acta Universitatis Lodziensis. Folia Oeconomica 326(6), 29-43.

Ustawa z dnia 8 marca 1990 r. o samorządzie gminnym (Dz. U. z 1990 r. Nr 16, poz. 95 z późn. zm.)

Ustawa z dnia 6 grudnia 2006 r. o zasadach prowadzenia polityki rozwoju (Dz. U. z 2006 r. nr 227, poz. 1658 z późn. zm.) 
Waligóra, A. (2015). Marka - marka miasta. Analiza procesu konstrukcji/rekonstrukcji wizerunku i rozumienia miasta. W: N. Krzyżanowska i K. Nowak (red.), Miejskie (trans)formacje. Toruń: Wydawnictwo Adam Marszałek.

Wiatrak, P. A. (2014). Uwarunkowania skuteczności narzędzi realizacji strategii rozwoju lokalnego i regionalnego. Marketing i Rynek, (5), 676-682.

Zakrzewska-Bielawska, A. (2014). Ewolucja szkół strategii: przegląd głównych podejść i koncepcji. Prace Naukowe Wałbrzyskiej Wyższej Szkoty Zarzadzania i Przedsiębiorczości, 27, 9-29.

Zintegrowane Inwestycje Terytorialne. (b.d.). Pobrano 9 maja 2019 z https://www.funduszeeuropejskie. gov.pl/strony/o-funduszach/zasady-dzialania-funduszy/zintegrowane-inwestycje-terytorialne

\title{
STRATEGIES OF COMMUNES IN POLAND IN 2011-2018. THE PERSPECTIVE OF APPROACHES TO STRATEGY
}

\begin{abstract}
The purpose of the research was to define the preferences regarding the approaches to strategy in Polish communes. The conducted research provided the basis to conclude that the planning approach towards strategies is the dominant one in Polish communes. This approach is expressed in focusing on material resources, on the internal development factors. The approach which is observed in communes to a lesser extent is the resource approach, the basis of which is focusing on non-material resources, and, similar to the case of the planning approach, on the internal factors. The positional approach focusing on the resources which differentiate and on the postulates regarding increasing the share in the market, the innovative approach, in which the communes focus on creating innovations, and the network approach focusing on relational resources and the usage of the network in development, even though they are justified from the point of view of the operation and development of a commune self-government, are only practiced by the communes to a small degree.
\end{abstract}

Keywords: strategic management, communal strategies, strategy theory. 